\title{
44. Ana dili olarak Türkçe eğitimindeki yaratıcı yazma tezlerine analitik bir bakış: Kapsam belirleme incelemesi
}

\section{Sümeyye KONUK ${ }^{1}$}

\begin{abstract}
APA: Konuk, S. (2021). Ana dili olarak Türkçe eğitimindeki yaratıcı yazma tezlerine analitik bir bakıș: Kapsam belirleme incelemesi. RumeliDE Dil ve Edebiyat Araştırmaları Dergisi, (22), 706733. DOI: $10.29000 /$ rumelide.899223.
\end{abstract}

\section{$\ddot{O} \mathbf{z}$}

Bu araştırmada, Türk yükseköğretimindeki yaratıcı yazma ile ilgili lisansüstü eğitim tezlerinin kapsamı incelenmiştir. Kapsam belirleme yaklaşımıyla 51 tez araştırmaya dahil edilmiştir. Veriler tematik olarak analiz edilmiştir. Sonuç olarak kronolojik olarak erken tarihli tezlerin daha özgün olduğu ve belirli hipotezlerin farklı tezlerde ortaklık gösterdiği görülmüştür. Yaratıcı yazmaya ilişkin tezlerde en fazla tekrar eden ilişkisel kapsam kurguları; yaratıcı yazma etkinliklerinin yaratıcı yazmaya, yazma becerisine, yazma tutumuna, ders tutumuna etkisi ve değişken bir x unsurunun yaratıcı yazmaya etkisi şeklindedir. Yaratıcı yazma üzerine yazılmış 51 tezden 39'unda ön ve son testli yarı deneysel model kullanılmıştır. Tezlerde test, ölçek, rubrik başlıklarında kullanılan 57 farklı veri toplama aracından 25’i yazarlar tarafından geliştirilmiştir. Test, ölçek, rubrik başlıklarında ölçme araçlarının kullanıldığı 43 tezden 28'inde tez yazarı herhangi bir ölçme aracı geliştirmeksizin hazır ölçme araçları kullanmıştır. 30 tezde ortaokul, 14 tezde ilkokul ve 3 tezde lise öğrencileriyle çalışılmış ve tezlerin uygulaması en kısa 4 hafta en uzun 18 hafta sürmüştür. Yaratıcı yazma etkinliklerinin yazma becerisini olumlu yönde etkilediği bulgusu 8 tezde, normal öğrencilerde yaratıcı yazma etkinliklerinin yazma tutumunu geliştirdiği bulgusu 8 tezde, yaratıcı dramanın yaratıcı yazma becerisini geliştirdiği bulgusu 4 tezde ortaya konulmuştur. Değişken bir $\mathrm{x}$ unsurunun yaratıcı yazmaya etkisini inceleyen 18 tezin tamamında öğrencilerin yaratıcı yazma becerileri kontrol grubu lehine olumlu yönde gelişmiştir. İncelenen tezlerin temel bulguları, yaratıcı yazmadaki belirli konuları, doygunluk noktasına taşması bakımından ve tezlerin özgünlüğü bakımından tartışılmış, bu doğrultuda öneriler sunulmuştur.

Anahtar kelimeler: Yaratıcı yazma, lisansüstü eğitim tezleri, kapsam belirleme yaklaşımı, Türkçe eğitimi

\section{An analytical analysis of theses about creative writing in Turkish education as a native language: A scoping review}

\footnotetext{
Abstract

In this research, the scope of the postgraduate thesis about creative writing was examined in Turkish Higher Education. With the scoping review, 51 theses have been included in the research. The data were analyzed thematically. As a result, it has been seen that the chronologically earlier theses were more original and certain hypotheses are common in different theses. The most recurring correlational scope builds are the effect of creative writing activities on creative writing, writing skill, writing attitude, course attitude, and the effect of a variable $\mathrm{x}$ element on creative writing. A semi-experimental model with pre and post-tests was used in 39 of 51 theses written on

Dr., Trakya Üniversitesi, Eğitim Fakültesi, Türkçe ve Sosyal Bilimler Eğitimi Bölümü, Türkçe Eğitimi ABD (Edirne, Türkiye), sumeyyekonuk@gmail.com, ORCID: 0ooo-0003-0896-0711 [Araştırma makalesi, Makale kayıt tarihi: 27.01.2021-kabul tarihi: 20.03.2021; DOI: 10.29000/rumelide.899223]

Adres $\mid$ Address

RumeliDE Dil ve Edebiyat Araşttrmaları Dergisi $\quad$ RumeliDE Journal of Language and Literature Studies Osmanağa Mahallesi, Mürver Çiçeği Sokak, No:14/8 Osmanağa Mahallesi, Mürver Çiçeği Sokak, No:14/8 Kadıköy - İSTANBUL / TÜRKIYE 34714 Kadıköy - ISTANBUL / TURKEY 34714 e-posta: editor@rumelide.com e-mail: editor@rumelide.com, tel: +90 505 7958124, +90 2167730616 phone: +90 505 7958124, +90 2167730616
} 
creative writing. 25 of the 57 different data collection tools used in the titles of tests, scales, and rubrics in thesis were developed by the authors. In 28 of 43 theses in which measurement tools were used in test, scale, rubric titles, the thesis author used ready-made measurement tools without developing any tools. 30 theses were studied with middle school students, 14 theses in primary school, and 3 theses with high school students. The execution of theses took 4 weeks at the shortest and 18 weeks at the longest. The results that creative writing activities affect writing skills positively affirmed eight times. It affirmed eight times that creative writing activities improve the writing attitude of normal students. It affirmed four times that creative drama improves creative writing skills. In all the theses examining the effect of a variable $\mathrm{x}$ element on creative writing, students' creative writing skills improved in favor of the control group. These common features have been discussed in terms of the saturation point of certain topics and the originality of the theses and recommendations are presented.

Keywords: Creative writing, postgraduate theses, scoping review, Turkish education

\section{Giriş}

Türkçe öğretmenliği programlarındaki 'Yaratıcı Yazma' seçmeli dersi bu araştırmanın motivasyonunu oluşturmuştur. Lisansüstü tezler yoluyla, araştırmacılar toplumun sosyal ve kültürel sermayesini inşa eder, entelektüel bilgi birikimi oluşturur. Lisansüstü eğitim en üst kademedeki eğitimdir. Bu sebeplerle bu araştırmada, yaratıcı yazma konusunun lisansüstü düzeyde nasıl ele alındığı ve lisansüstü düzeyde oluşan bilgi birikimine ulaşılmak amaçlanmıştır.

Türkçe eğitimi alanında lisansüstü tezlere yönelik yürütülmüş çeşitli araştırmalar bulunmaktadır. 2011-2015 ylları arasındaki Türkçe eğitimi alanındaki lisansüstü tezlerin \%20.1’i öğretim strateji, yöntem ve teknik, \%17.5’i okuma eğitimi, \%13.6'sı yazma eğitimi, \%13.2 ders kitapları, \%11.3'ü yabancllara Türkçe öğretimi alanında yürütülmüştür (Özçakmak, 2017). Görüldüğü üzere temel dil becerilerinden dinleme bu sıralamaya girememiştir. Bu sonucu destekleyecek şekilde 1998-2013 yılları arasında Türkçe eğitiminde dinleme eğitimiyle alakalı tezleri tarayan bir araştırma dinleme eğitiminin lisansüstü tezlerde diğer dil becerilerinden daha az ele alındığını ortaya koymaktadır (Doğan ve Özçakmak, 2014). 1981-2012 yılları arasında, yabancılara Türkçe öğretimi alanında yayınlanmış lisansüstü tezlerde, temel konuların \%25.85'iyle dil bilgisi yanlışlarına ve \%11,56'yla Yabancılara Türkçe öğretimi ders kitaplarına odaklandığı görülmektedir (Büyükikiz, 2014). Türkçe öğretiminde şiir üzerine yapılan lisansüstü tezlerin ise şiirlerin içeriğini farklı açılardan incelenmesi, Türkçe ders kitaplarındaki şiirlerin değerler ve çocuk gelişimi bakımından değerlendirilmesi, şiirin dört temel dil becerisi açısından incelenmesi konularında olduğu görülmektedir (Şeref, 2019). Türkçe eğitimi alanında, 2020 yılına kadar 110 lisansüstü tez değerler eğitimi üzerine (Direkci, Akbulut ve Şimşek, 2020), 43 tez akıcı okuma becerisi üzerine (Maden, 2020), 50 tez Türkçe eğitimi ve çocuk edebiyatında toplumsal cinsiyet üzerine (Özbaşı ve Kalenderoğlu, 2020), 2017 yılına kadar 48 tez akademik yazma üzerine (Kan, 2017), 2019 yılına kadar 29 tez yaratıcı drama yöntemiyle planlanmış Türkçe öğretimi üzerine (Keşaplı, 2019), 2019 yllına kadar 129 tez yabancllara Türkçe öğretimi üzerine (Bağcl-Ayrancl, 2019) yürütülmüştür. Dünya çapında yazma becerisi ile ilgili makalelerde son yıllarda akademik yazma konu alanının önem kazandığı görülmektedir (Karagöz ve Şeref, 2020). Türkçe eğitimi alanında 19952018 yılları arasında toplam 275 doktora tezi bulunmaktadır ve bu tezlerden 120'si temel dil becerileri ile ilgilidir (46'sı yazma, 42'si okuma, 12'si dinleme, 11'i konuşma, 9'u birkaç dil becerisi bir arada) (Boyacı ve Demirkol, 2018). Doktora tezlerinde temel dil becerileri arasında yazmanın ön plana çıktığı görülmektedir. Alanyazın tarandığında, Türkçe eğitiminde lisansüstü düzeydeki yaratıcı yazma

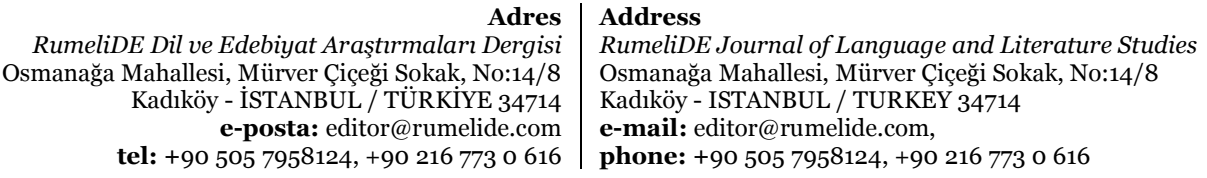


An analytical analysis of theses about creative writing in Turkish education as a native language: A scoping review / S. Konuk (pp. 706-733)

çalışmalarını değerlendiren bir çalışmaya rastlanmamıştır. İlköğretim düzeyinde ve Türkçe Öğretmenliği programlarında yaratıcı yazma ayrı bir ders olarak yer almaktadır. Bu araştırmada yaratıcı yazmaya ilişkin lisansüstü tezler analitik bir bakış açısı ile ele alınmıştır.

Yaratıcı yazma, bilgiyi nesnel olarak ileten yazılar haricindeki kişinin kendini özgünce ifade edebildiği her türlü orijinal yazıdır. Yaratıcı yazma disiplinler arası bir konudur. Edebiyat, sanat, dil eğitimi, yabancı dil eğitimi, dil bilim, psikoloji gibi alanlarda araştırmalara konu olmuş ve olmaya devam etmektedir. Psikoloji alanında yaratıcı yazma, zihinsel sıkıntısı olan hastaların iyileşmesini ve refahını destekleyebilecek bir faaliyettir (Punzi, 2020). Yaratıcı yazma sürecindeki deneyimsel öğrenme, bireylerin yaratıcı bir şekilde yazarken zor duygularını bilişsel olarak işlenmesini sağlamakta ve bunun terapötik etkileri bulunmaktadır (Deveney, 2020). Yaratıı yazma grupları şeklinde atölye çalışmaları HIV ile yaşayan gençlerin kişisel gelişimini ve azalan izolasyonunu desteklemekte ve yaratıcı yazma bir terapi olarak gençlere yarar sağlamaktadır (Fair ve ark., 2020). Psikoloji alanının yanı sıra yaratıcı yazma, yaşam boyu öğrenme sürecini destekleyecek etkili bir yazma modeli olarak ele alınmaktadır (Castleberry, Ward ve Stein, 2019). Örgün eğitimdeki yaratıcı yazma uygulamaları öğrencilerin kalem ve kâğıt yazarından "siber yazara" dönüşümünü ve bunların yaratıcı yazma üzerindeki etkilerine odaklanmaktadır (Skains, 2017). İkinci bir dilde yaratıcı yazmak ise dilbilgisi hataları, deneyim eksikliği, yanlış kullanılan ifadeler, metni iyi biçimlendirilememe gibi konularda yazar için zorluklar oluşturmaktadır (Turnbull, 2019). Yaratıcı yazma, gözlem ve yansıtma becerilerini geliştirmekte mesleki gelişime yardımcı olmaktadır (Hatem ve Ferrara, 2001). Okul dışında ise yaratıcı yazma bir kariyer ve meslek olarak görülmektedir. Yaratıcı yazmanın disiplinler arası doğasına uygun olarak öğretmenler, dilbilimciler, psikologlar, yazarlar ve sanat eğitimcileri ile yürütülen bir araştırmada yaratıcı yazmanın temel bileşenleri gözlem, hayal gücü ve içsel motivasyon olarak bulunmuştur (Barbot ve ark., 2012). Bu görüşü destekleyecek şekilde çocuklarla yürütülen bir araştırmada, duygu odaklı düşünmenin, çocukların yaratıcı yazma etkinliklerini merkezi bir önemde desteklediği görülmüştür (Vass, 2007). Yaratıcı yazma faaliyetlerinin yapıldığı bir sınıf gözleminde, işbirlikçi zeminin içerik oluşturmada karşılıklı ilhamı kolaylaştırması ve öğrenci duyguları yaratıcı yazma söyleminin iki önemli yönünü oluşturmuştur (Vass ve ark., 2008). Görüldüğü üzere yaratıcı yazma, okuyucunun zihninde güçlü bir imge yaratmak için duyuları ve duyguları kullanmaktadır. Yaratıcı yazıların diğer yazı türlerine kıyasla daha fazla eğlendirmesi, aydınlatması veya ilham vermesi gerekir. McVey (2008), İngiltere'de yürüttüğü araştırmasında, yükseköğretim öğrencilerinin yazma konusundaki isteksizliklerinin üstesinden gelindiğinde, öğrencilerin metin yaratma konusunda güçlü ve özgür olduğunu göstermiştir. Yazara göre özgün bir biçimde üretilmiş her yazı yaratıcı yazıdır. McVey’in (2008) görüşünde olduğu gibi çoğunlukla yaratıcı yazma dışında tutulan akademik yazıların da yaratıcı yazmaya dahil edilmesi gerektiği yönünde görüşler bulunmaktadır. Yoo (2017), baskın kuramsal nesnel söylemlerin bireyin kişisel yaratıcı sesini kıstığını, akademik yazının baskılara karşı çıkması gerektiğini savunur ve böylece bireylerin insan deneyiminin tüm zenginliğini kapsayan araştırmalar üretebileceğini söyler.

Yaratıcı yazma ve yazarlık eğitimlerinin sayısının her geçen gün artması, yaratıcı yazmaya ilgi duyan insanların sayısının arttığı anlamını taşımaktadır. Peki, bireylere yaratıcı yazmayı öretmek mümkün müdür? Bu sorunun cevabını araştıran Thomson (2013), çalışmasında, yaratıcı yamayı öğretmenin mümkün olduğunu, bu konudaki asıl sorunun yaratıcı yazma eğitmenlerinin yaratıcı yazmayı öğretmek için yeterli olmadığını söylemektedir. Bu tezi destekleyecek şekilde, Rebecca'nın (2016) araştırması, ABD'de 33 lisansüstü yaratıcı yazma programı bulunduğunu, lisansüstü yaratıcı yazarlık öğrencileri için disipline özgü pedagojik eğitimin eksik olduğunu göstermektedir. Bu görüşlerin aksine yaratıcı yazma konusunu etiyolojik olarak ele alan bir araştırma, yaratıcı yazma becerisinin öğrenme

\begin{tabular}{r|r} 
Adres & Address
\end{tabular}

Dergisi $\quad$ RumeliDE Journal of Language and Literature Studies

Osmanağa Mahallesi, Mürver Çiçeği Sokak, No:14/8 Osmanağa Mahallesi, Mürver Çiçeği Sokak, No:14/8

Kadıköy - İSTANBUL / TÜRKIYE 34714 Kadıköy - ISTANBUL / TURKEY 34714

e-posta: editor@rumelide.com

tel: +90 505 7958124, +90 $2167730616 \quad \begin{aligned} & \text { e-mail: editor@rumelide.com, } \\ & \text { phone: +90 505 7958124, +90 } 2167730616\end{aligned}$ 
ve öğretme süreçlerinden ziyade ailevi kalıtıma bağlı olduğunu göstermektedir (Tan ve Grigorenko, 2013). Tan ve Grigorenko (2013), 511 çocuk ve anne babaları ile yürüttüğü araştırmalarında, ailevi kalıtımın yaratıcı yazma göstergelerinin üzerindeki rolüne odaklanmış, araştırma modeline başka bilişsel ve çevresel faktörler eklendiğinde bile yaratıcı yazmanın ailevi ve kalıtımsal olduğu sonucuna ulaşmıştır.

Alanyazından hareketle yaratıcı yazma konusunun hem örgün hem de yaşam boyu öğrenmede önemli bir yerinin olduğu görülmektedir. Bir birey küçük yaşlarda yaratıcı yazma becerisi kazandığı taktirde yaşam boyu öğrenmeye yatkınlık, pozitif yönde bir ruh sağlığı, bir meslek sahibi olma potansiyeli gibi olumlu edinimleri olabilmektedir. Bu araştırmanın ana dili olarak Türkçe Eğitiminde, lisansüstü düzeyde yaratıcı yazmanın yerini ortaya koyarak alanyazına katkı sağlaması umulmaktadır.

\section{Yöntem}

Yaratıcı yazma ile ilgili alınyazının bu derlemesinde kapsam belirleme yaklaşımı kullanılmıştır (Levac ve ark., 2010). Kapsam belirleme yaklaşımının en genel amacı, mevcut bulguları belirlemek ve haritalandırmaktır (Arksey, H., ve O’Malley, L., 2005). Kapsam belirleme bir konu için yapılmış araştırmaların kapsamının, gözden geçirilmesi, araştırma alanı içindeki sonuç çeşitliliğ̈inin incelenmesi veya araştırma literatüründeki boşlukların belirlenmesi amacıyla kullanılır (Pham ve ark., 2014). Munn ve ark. (2018) kapsam belirlemenin amaçlarını; belirli bir alanda mevcut bulgu türlerini belirlemek, alınyazındaki temel kavramları/tanımları netleștirmek, belirli bir konu veya alanda araştırmanın nasıl yapıldığını incelemek, bir konseptle ilgili temel özellikleri veya faktörleri belirlemek, bilgi boşluklarını belirlemek ve analiz etmek, şeklinde sıralar.

Kapsam belirleme incelemesinin beş aşaması şu şekildedir; araştırma sorularını belirleme, ilgili çalışmaları belirleme, belirlenenler arasından çalışma seçme, verilerle çizelge oluşturma, sonuçları harmanlama, özetleme ve raporlama (Arksey, H., ve O'Malley, L., 2005). Bu araştırmada, kullanılan metodun doğasına uygun olarak bu aşamalar takip edilmiş ve makalenin sunumu buna göre yapılmıştır.

Birinci aşama: Araştırma soruları, araştırılan konunun kapsamını yakalayacak şekilde oluşturulmuştur. Bu araştırmada kapsam, ana dili eğitimindeki yaratıcı yazma tezleridir. Araştırma soruları şöyledir:

1. Yaratıcı yazma tezlerinin tür ve amaç bakımından kapsamı nedir?

2. Yaratıcı yazma tezlerinin çalışma deseni, katılımcılar ve süre bakımından kapsamı nedir?

3. Yaratıcı yazma tezlerinin veri toplama araçları bakımından kapsamı nedir?

4. Yaratıcı yazma tezlerinin temel bulgular bakımından kapsamı nedir?

İkinci ve üçüncü aşama: İlgili çalışmaları belirleme ve seçme aşamasında, Türkiye Yüksek Öğretim Kurulu Başkanlığı tez merkezi veri tabanı kullanılmıştır. Yaratıcı yazma ile ilgili lisansüstü eğitim tezleri veri tabanı üzerinden taramalarla belirlenmiştir. Belirleme yapılırken eğitim bilimleri alanı filtresi kullanılmıştır. Tezlerden başlı̆̆ında ve anahtar kelimelerinde 'yaratıcı yazma' ifadesi bulunanlar taranmış ve araştırmaya dahil edilmiştir. Türkçenin ikinci dil olarak öğretilmesi konusunda yürütülen yaratıcı yazmaya ilişkin tezler kapsam dışında tutulmuştur. Ana dili olarak Türkçede, odağında ve başlığında yaratıcı yazma bulunan bütün tezler çalışmaya dahil edilmiştir.

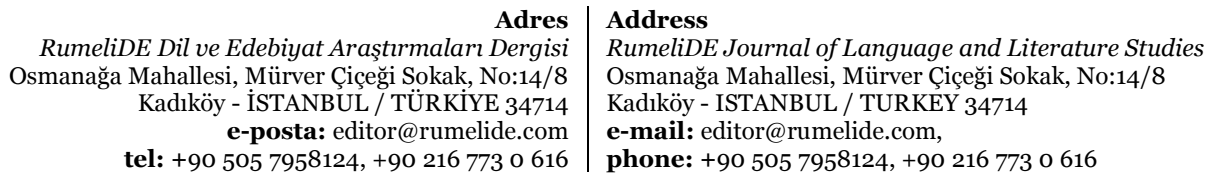


An analytical analysis of theses about creative writing in Turkish education as a native language: A scoping review / S. Konuk (pp. 706-733)

Tablo 1. Yaratıcı yazmaya ilişkin lisansüstü tezlerin yazar-eser adıyla kronolojik listesi

1. Demirbaş (2005) Biyoloji öğretiminde yaratıcı yazma uygulamaları

2. Maltepe (2006) Yaratıcı yazma yaklaşımı açısından Türkçe derslerindeki yazma süreçlerinin ve ürünlerinin değerlendirilmesi

3. Kapar Kuvanç (2008) Yaratıcı yazma tekniklerinin öğrencilerin Türkçe dersine ilişkin tutumlarına ve Türkçe dersindeki başarılarına etkisi

4. Beydemir (2010) İlköğretim 5. sınıf Türkçe dersinde yaratıcı yazma yaklaşımının yazmaya yönelik tutumlara, yaratıcı yazma ve yazma erişisine etkisi

5. Özdemir (2010) Üstün yetenekli öğrencilerde yaratıcı yazma çalışmalarının düzeyleri ilköğretim 6,7 , 8. sınıf örneği

6. Tonyalı (2010) Yaratıcı yazma uygulamalarının ilköğretim altıncı sınıf öğrencilerinin yazma becerilerine etkisi

7. Kırbaş (2010) Yeni Türkçe ders programına göre ilköğretim yedinci sınıf öğrencilerinin yaratıcı yazma çalışmalarının yazım noktalama ve planlama açısından değerlendirilmesi

8. Duran (2010) Yaratıcı yazma yaklaşımının yazılı anlatım becerisinin gelişimine etkisi

9. Demir (2011) İlköğretim öğrencilerinin yaratıcı yazma becerileri ile yazma özyeterlik algısı ve başarı amaç yönelimi türleri ilişkisinin değerlendirilmesi

10. Akdal (2011) Metinler arası okuma yaklaşımının ilköğretim beşinci sınıf öğrencilerinin yaratıcı yazma becerilerine etkisi

11. Türkel (2011) Yaratıcı dramanın yaratıcı yazma başarısına ve yazmaya karşı tutuma etkisi (ilköğretim 8. sınıf)

12. Ak (2011) Yaratıcı yazma tekniklerinin ilköğretim 5.sınıf öğrencilerinin Türkçe dersindeki yazılı anlatım becerileri üzerindeki etkisi

13. Bulut (2012) 2006 Türkçe dersi $(6,7,8$. sınıflar) öğretim programında yer alan yazma kazanımlarının yaratıcı yazmaya uygunluğu

14. Başkök (2012) İlköğretim yedinci sınıf öğrencilerinde uygulanan yaratıcı yazma çalışmalarının, öğrencilerin yaratıcılıklarına ve Türkçe dersine olan tutumlarına etkisinin incelenmesi

15. Erdoğan (2012) Süreç temelli yaratıcı yazma uygulamalarının yazılı anlatım becerisine ve yazmaya ilişkin tutuma etkisi

16. Sever (2013) Süreç temelli yazma modellerinin ilkokul dördüncü sınıf öğrencilerinin yazılı anlatım ve yaratıcı yazma becerilerine etkisi

17. Avcı (2013) Yaratıcı yazma etkinliklerinin 8. sını öğrencilerinin yazma eğilimleri ve yazma kaygılarına etkisi

18. Duru (2014) Altıncı sınıf öğrencilerinin yaratıcı yazma becerilerini geliştirmeye yönelik stratejilerin etkililiğinin değerlendirilmesi

19. Peker (2015) Yazılı anlatım becerilerinin geliştirilmesinde yaratıcı drama tekniklerinden özel mülkiyet tekniğinin yaratıcı yazma yaklaşımı ile karşılaştırılması

20. Korkmaz (2015) Yaratıcı yazma yönteminin 6. sınıf öğrencilerinin yazma öz yeterlik algılarına, yazmaya ilişkin tutumlarına ve yazma becerisi akademik başarılarına etkisi

21. Urhan (2016) Ortaokul 8. sınıf Türkçe derslerinde masalların yaratıcı yazma becerisine etkisi

22. Yüksel (2016) Ortaokul 5.sınıf Türkçe derslerinde uygulanan yaratıcı yazma etkinliklerinin öğrencilerinin yazmaya yönelik tutumlarına ve sözel yaratıcılıklarına etkisinin incelenmesi

23. Saluk (2017) Üstün yeteneklilerde yaratıcı yazma becerilerinin geliştirilmesi üzerine bir araştırma

24. Oğuz (2017) Masalları birleştirme yoluyla ortaokul öğrencilerinin yaratıcı yazma becerilerinin incelenmesi

25. Dolmaz (2017) Sosyal bilgiler öğretiminde tarihsel roman kullanımının yaratıcı yazma becerilerine etkisi

26. Dalkılıç Fer (2017) İlköğretim öğrencilerinin yaratıcı yazı çalışmalarının süreç içerisindeki gelişimlerinin incelenmesi ve değerlendirilmesi

27. Yıldırım (2018) Yaratıcı yazma etkinliklerinin Türkçe öğretmeni adaylarının yazma becerisine etkisi

28. Karadă̆ (2018) Öğretim teknolojilerinden Storybırd uygulamasının 5. sınıf öğrencilerinin yaratıcı yazma becerilerine ve yazmaya yönelik tutumlarına etkisi

29. Kılıç (2018) 9. sınıf öğrencilerine uygulanan drama yöntemine dayalı yaratıcı yazma çalışmalarının yazma tutumuna etkisinin incelenmesi

30. Dorlay (2018) 5 E öğrenme modeline uygun yaratıcı yazma etkinliklerinin ortaokul öğrencilerinin yazma becerisi üzerine etkisi

31. Karataş (2019) Sorumluluk değerinin yaratıcı yazma teknikleri ile oluşturulan etkinliklerle kazandırılmasının öğrencilerin sorumluluk düzeyine etkisi

32. Yılmaz (2019) Türk halk edebiyatı unsurlarının türkçe öğretiminde kullanımı ve yaratıcı yazmaya etkisi

Adres

RumeliDE Dil ve Edebiyat Araşttrmaları Dergisi Osmanağa Mahallesi, Mürver Ciçeği Sokak, No:14/8 Kadıköy - ISTANBUL / TÜRKIYE 34714 e-posta: editor@rumelide.com tel: +90 $5057958124,+902167730616$
Address

RumeliDE Journal of Language and Literature Studies

Osmanağa Mahallesi, Mürver Çiçeği Sokak, No:14/8

Kadıköy - ISTANBUL / TURKEY 34714

e-mail: editor@rumelide.com,

phone: +90 505 7958124, +90 2167730616 
33. İsbir Abrekoğlu (2019) Yaratıcı dramanın yaratıcı yazma becerisine ve yazmaya yönelik tutuma etkisi

34. Kasap (2019) Yaratııı okuma-yaratıcı yazma çalışmalarının yaratııı okuma, okuduğunu anlama, yazma ve yaratıcı yazma erişisine etkisi

35. Kalaç (2019) Klasik Türk edebiyatı çeviri örneklerinin yaratıcı yazma becerilerine katkısı

36. Et (2019) Karikatürle yazma çalışmalarının ortaokul öğrencilerinin yaratıı yazma becerisine etkisi

37. Uslu (2019) İşbirlikli dijital hikâye anlatımının ilkokul 4. sınıf öğrencilerinin yaratıcı yazma ve sosyal duygusal öğrenme becerilerine etkisi

38. Erdoğan (2019) İlkokul 4. sınıf türkçe dersinde yansıtıcı düşünme destekli yaratıcı yazma çalışmalarının öğrencilerin yaratıc yazma becerilerine etkisinin incelenmesi

39. Duman Yeğen (2019) İlkokul 3. sınıf öğrencilerinin yaratıcı yazma becerilerinin yaratıcı drama yöntemiyle geliştirilmesine yönelik bir eylem araştırması

40. Demirbaş (2019) Dijital öykülerin ilkokul öğrencilerinin dinlediğini anlama ve yaratıcı yazma becerilerine etkisi

41. Uluyüz (2019) Alternatif dinleme/izleme materyallerinin ortaokul öğrencilerinin yaratıcı yazma becerilerine etkisi

42. Uyğun (2019) 2018 Türkçe dersi öğretim programındaki yazma kazanımlarının ve ders kitaplarındaki etkinliklerin yaratıcı yazma becerisine uygunluğunun incelenmesi

43. Uç (2019) Yazma destekli argümantasyon uygulamalarının 7.sınıf öğrencilerinin yazma öz yeterliklerine, yaratıcı yazmalarına ve kavram öğrenmelerine etkisinin incelenmesi

44. Bayer (2019) Bazı yaratıcı yazma teknikleri kullanılarak lise öğrencilerinin fiziğe yönelik görüşlerinin belirlenmesi

45. Uluyüz (2019) Alternatif dinleme/izleme materyallerinin ortaokul öğrencilerinin yaratıcı yazma becerilerine etkisi

46. Gökçe (2020) İlkokul dördüncü sınıf Türkçe dersinde yaratıcı yazma uygulamalarının öğrencilerin Türkçe dersi tutumu, yazma tutumu ve yaratıcı yazma becerileri üzerine etkisi

47. Akbaba (2020) Yaratıcı yazma çalışmalarını öyküleyici metin yazma becerisine ve ileri okuma farkındalığına etkisi

48. Karataş (2020) İlkokul dördüncü sınıf öğrencilerinin yaratıcı hikâye yazma becerilerinin geliştirilmesi

49. Razgatlığlu (2020) Etkinlik temelli şiir çalışmalarının akıcı okuma, yaratıcı yazma ve tutumlara etkisi

50. Taç (2020) Araştırmacı yazma yaklaşımının ilkokul 3. sınıf öğrencilerinin yaratıcı ve akııı hikâye yazma becerisine etkisi

51. Aydın (2020) Yaratıcı düşünmenin yaratıcı yazmaya etkisi

Tablo 1'de görüldüğü üzere 51 tez kapsam belirleme incelemesine dahil edilmiştir. Kronolojik olarak değerlendirildiğinde, tezlerin \%41’i 2019 ve 2020 yllına aittir. 2019 yllı 15 tez ile yaratıcı yazma konusunun en çok ele alındığı yıl olmuştur. 2019 yılına gelene kadar her ylla ait en fazla 5 yaratıcı yazma tezi bulunmaktadır [2005(1), 2006(1), 2008(1), 2010(5), 2011(4), 2012(3), 2013(2), 2014(1), 2015(2), 2016(2), 2017(4), 2018(4), 2019(15), 2020(6)].

Dördüncü aşama: Kapsam belirleme araştırmasında, çizelge oluşturma aşaması, incelenen çalışmalardan veri elde etmede kullanılan tekniklere işaret eder (Arksey, H., ve O’Malley, L., 2005). Bu araştırmada tezler nitel bir yaklaşımla analiz edilmiştir. Giderek detaylanacak şekilde dört fazlı bir kodlama sistemi kullanılmıştır. İlk fazda tezlerde ortak bölümler olan amaç, yöntem, katılımcılar, ana sonuçlar kodlanmıştır. İkinci fazda ilk kodlamadaki her bir başlık araştırma sorularını cevaplayacak şekilde alt başlıklarla kodlanmıştır. Üçüncü fazda benzer kodlar belirlenerek kod kümeleri birleştirilmiştir. Dördüncü fazda tematik veriler, karşlaş̧tırma yapılabilecek şekilde tabloya aktarılmıştır. Tezler (1) tür ve amaçları, (2) çalışma deseni katılımcılar ve süre, (3) veri toplama araçları, (4) temel sonuçlar bakımından dört kategoride incelenmiştir. Bu dört kategoriye ilişkin kodlama formu Nvivo Pro 11 nitel analiz programı içinde oluşturulmuştur. Analiz sürecinde geçerlilik ve güvenirliğin sağlanması amacıyla, kategoriler ve kodlara ilişkin dallanmış yapı iki alan uzmanın

\footnotetext{
RumeliDE Dil ve Edebiyat Araștırmaları Dergisi Osmanağa Mahallesi, Mürver Ciceği Sokak, No:14/8 Kadıköy - ISTANBUL / TÜRKIYE 34714 e-posta: editor@rumelide.com 
görüşüne sunulmuş ve uzman görüşleri doğrultusunda kodlama işlemleri güncellenmiş ve iyileştirilmiştir. Kodları isimlendirme aşamasında iki alan uzmanının rehberliğinden faydalanılmıştır.

Beşinci aşama: Sonuçları harmanlama aşamasında, nitel analiz sonrasında ulaşılan bulgular kapsam belirleme yönteminin doğasına göre özetlenmiş ve raporlanmıştır. Harmanlama, araştırma soruları doğrultusunda ulaşlan verilerin tematik bir analizini ve betimleyici sayısal bilgilerini okuyucuya sunmaktadır.

\section{Bulgular}

Bulgular bölümü boyunca 51 yaratıcı yazma tezi tablolar aracıllğıyla özetlenmiştir. Bulgular araştırma soruları doğrultusunda okuyucuya sunulmuştur.

\section{Tür ve amaçlar bakımından analitik bakış}

Tezlerden 16'sı Sınıf Eğitimi alanında, 24’ü Türkçe Eğitimi alanındadır (bk. Tablo 2). Geri kalan 11 tez, Eğitim Bilimleri Anabilim Dalı (3 tez), Eğitim Programları ve Öğretim Programı (2 tez), Türk Dili ve Edebiyatı Eğitimi (1 tez), Biyoloji Eğitimi (1 tez), Fen Eğitimi (1 tez), Fizik Eğitimi (1 tez), Yaratıcı Drama Yüksek Lisans Programı (1 tez), Sosyal Bilgiler Eğitimi (1 tez) alanlarındadır. 51 tezin 44’ü yüksek lisans 7'si doktora düzeyindedir.

Kapsam belirlemenin doğası gereği yaratıcı yazma ile ilgili alınyazındaki temel kavramları/tanımları netleştirmek için tezlerin amaç cümlelerindeki yaratıcı yazma için kullanılan ifadeler incelenmiştir. İfadeler şöyledir:

* Yaratıcı yazma becerisi (17 tez, bk. Tablo 2 (sira 1, 9, 11, 25, 26, 27, 29, 31, 32, 35, 36, 40, 41, 42, 43, $47,50)$

* Yaratıcı yazma etkinliği (9 tez, bk. Tablo 2 (sıra 1, 5, 7, 10, 14, 15, 37, 47, 48))

* Yaratıcı yazma çalışması (8 tez, bk. Tablo 2 (sıra 4, 13, 16, 20, 24, 33, 40, 46))

* Yaratıcı yazma teknikleri (5 tez, bk. Tablo 1)

* Yaratıcı yazma yaklaşımı (3 tez, bk. Tablo 2 (sıra 2, 6, 28))

* Yaratıcı yazma uygulaması (2 tez, bk. Tablo 2 (sira 19, 30))

* Yaratıcı yazma yöntemi (1 tez, bk. Tablo 2 (sıra 12)

Tablo 2. Yaratıcı yazma tezlerinin alanı, türü ve amaçları

1. Demirbaş (2005), Yüksek lisans tezi, Biyoloji Eğitimi, Yaratıcı yazma etkinlikleriyle zenginleştirilen Biyoloji dersinin, farklı yaratıcılık düzeyindeki öğrencilerin yaratıcı yazma becerilerine, derse yönelik tutum ve akademik başarı düzeylerine etkilerini incelemek

2. Maltepe (2008) Doktora tezi, Türkçe Eğitimi, Türkçe derslerindeki yazma uygulamalarını ve öğrencilerin yazılı anlatım çalışmalarını yaratıcı yazma yaklaşımının özellikleri açısından değerlendirmek

3. Kapar Kuvanç (2008) Yüksek lisans tezi, Türkçe Eğitimi, Yaratıcı yazma tekniklerinin öğrencilerin Türkçe dersine ilişkin tutum ve akademik başarıları üzerindeki etkisini belirlemek

4. Kırbaş (2010) Yüksek lisans tezi, Türkçe Eğitimi, Öğrencilerin yaratıcı yazma çalışmalarında yaptıkları yazım, noktalama kurallarının uygulamasını ve plânlama hatalarını tespit etmek

\begin{tabular}{r|l} 
Adres & Address \\
RumeliDE Dil ve Edebiyat Araştırmaları Dergisi & RumeliDE Journal of Language and Literature Studies \\
Osmanağa Mahallesi, Mürver Çiçeği Sokak, No:14/8 & Osmanağa Mahallesi, Mürver Çiçeği Sokak, No:14/8 \\
Kadıköy - İSTANBUL / TÜRKIYE 34714 & Kadıköy - ISTANBUL / TURKEY 34714 \\
e-posta: editor@rumelide.com & e-mail: editor@rumelide.com, \\
tel: +90 505 7958124, +90 216 773 0 616 & phone: +90 505 7958124, +90 216773 o 616
\end{tabular}


5. Duran (2010) Yüksek lisans tezi, Sınıf Eğitimi, Klasik tekniklere uygun hazırlanan etkinlik örnekleri ve yaratıcı yazma etkinlik örneklerini karşılaştırmak

6. Beydemir (2010) Yüksek lisans tezi, Sınıf Eğitimi, Yaratıcı yazma yaklaşımının yaratıcı yazmaya, yazma erişişine ve yazmaya yönelik tutuma etkisini tespit etmek

7. Tonyalı (2010) Yüksek lisans tezi, Türkçe Eğitimi, Yaratıcı yazma etkinliklerinin öğrencilerin metin yazma becerilerinin geliştirilmesinde ve yaratıcılık seviyelerinin artmasında etkili olup olmadığı incelemek

8. Ak (2011) Yüksek lisans tezi, Sınıf eğitimi, Yaratıcı yazma tekniklerinin yazılı anlatım becerileri üzerindeki etkisini ve yazılı anlatıma yönelik tutumlarını belirlemek

9. Demir (2011) Doktora tezi, Türkçe Eğitimi, Öğrencilerinin yaratıcı yazma becerileri ile yazma özyeterlik algıSı ve başarı amaç yönelimi türleri ilişkisini değerlendirmek

10. Avcı (2013) Yüksek lisans tezi, Türkçe Eğitimi, Yaratıcı yazma etkinliklerinin öğrencilerinin yazma eğilimleri ve yazma kaygllarına etkisi olup olmadığını belirlemek

11. Duru (2014) Yüksek lisans tezi, Türkçe Eğitimi, Yaratıcı yazma becerilerini geliștirmeye yönelik stratejilerin etkililiğini değerlendirmek

12. Korkmaz (2015) Yüksek lisans tezi, Eğitim Bilimleri Anabilim Dalı, Yaratıcı yazma yönteminin ve yazma becerisi akademik başarısına, yazma becerisi öz yeterlik algısına, yazmaya ilişkin tutuma etkisini incelemek

13. Başkök (2012) Yüksek lisans tezi, Eğitim Programları ve Öğretim, Yaratıcı yazma çalışmalarının, öğrencilerin yaratıcılıklarına ve Türkçe dersine olan tutumlarına etkisini incelenmek

14. Yüksel (2016) Yüksek lisans tezi, Eğitim Bilimleri Anabilim Dalı, Yaratıcı yazma etkinliklerinin öğrencilerin yazmaya yönelik tutumlarına ve sözel yaratıcılıklarına etkisini incelemek

15. Yıldırım (2018) Yüksek lisans tezi, Türkçe Eğitimi, Yaratıcı yazma etkinliklerinin yazma becerisine ve yazmaya karşı tutuma etkisi

16. Akbaba (2020) Doktora tezi, Türkçe Eğitimi, Yaratıcı yazma çalışmalarının öyküleyici metin yazma becerisine ve ileri okuma farkındalık düzeyine olan etkisini belirlemek

17. Taç (2020) Yüksek lisans tezi, Sınıf Eğitimi, Araştırmacı yazma yaklaşımının öğrencilerinin yaratıcı ve akıcı hikâye yazma becerilerine etkisini belirlemek

18. Karataş (2020) Yüksek lisans tezi, Sınıf Eğitimi, Öğrencilerinin yaratıcı hikâye yazma becerilerini geliştirmek

19. Gökçe (2020) Yüksek lisans tezi, Sınıf Eğitimi, Yaratıcı yazma uygulamalarının öğrencilerin yaratıcı yazmalarına, Türkçe dersi tutumuna, yazma tutumuna olan etkisini belirlenmek

20. Kasap (2019) Doktora tezi, Türkçe Eğitimi, Yaratıcı yazma çalışmalarının öğrencilerinin yazma, yaratıcı yazma erişilerine, yaratıcı okuma ve okuduğunu anlama, etkisini belirlemek

21. Karataș (2019) Yüksek lisans tezi, Sınıf Eğitimi, Sorumluluk değerinin yaratıcı yazma teknikleri ile oluşturulan etkinliklerle kazandırılmasının öğrencilerin sorumluluk düzeyine etkisini belirlemek

22. Razgatlığlu (2020) Yüksek lisans tezi, Sınıf Eğitimi, Etkinlik temelli şiir çalışmalarının akıcı okuma, şiir ve yaratıcı yazmaya yönelik tutumlarına etkisini belirlemek

23. Türkel (2011) Doktora tezi, Türkçe Eğitimi, Yaratıcı dramanın yaratıcı yazma başarısına ve yazmaya karşı tutuma etkisi

24. Kılıç (2018) Yüksek lisans tezi, Türk Dili ve Edebiyatı Eğitimi, Drama yöntemine dayalı yaratıcı yazma çalışmalarının öğrencilerin yazma tutumlarına etkisini incelemek

25. Erdoğan (2018) Yüksek lisans tezi, Sınıf Eğitimi, Yaratıcı drama yönteminin öğrencilerinin yaratıcı yazma becerilerine etkisini görmek

26. Duman-Yegen (2019) Yüksek lisans tezi, Sınıf Eğitimi, Yaratıcı drama yönteminin yaratıcı yazma becerisine etkisini ortaya koymak

27. İsbir-Abrekoşlu (2019) Yüksek lisans tezi, Eğitim Programları ve Öğretim, Yaratıcı drama ile yapılan yaratıcı yazma öğretiminin yaratıcı yazma becerilerine ve yazmaya yönelik tutuma etkisini belirlemek

28. Peker (2015) Yüksek lisans tezi, Yaratıcı Drama Yüksek Lisans Programı, Öğrencilerin yazılı anlatım becerilerinin geliştirilmesinde yaratıcı drama tekniklerinden özel mülkiyet/yarım bırakılmış materyal tekniğinin yaratıcı yazma yaklaşımı ile karşılaştırılması

29. Akdal (2011) Yüksek lisans tezi, Sınıf Eğitimi, Metinler arası okuma yaklaşımının yaratıcı yazma becerilerine etkisi

30. Erdoğan (2012) Doktora tezi, Sınıf Eğitimi, Süreç temelli yaratıcı yazma uygulamalarının yazılı anlatım becerisine ve yazmaya ilişkin tutuma etkisini ve bu sürece ilişkin öğrenci ve öğretmen görüsslerini belirlemek

31. Sever (2013) Yüksek lisans tezi, Sınıf Eğitimi Süreç temelli yazma modellerinin yazılı anlatım ve yaratıcı yazma becerilerine etkisi incelemek

32. Urhan (2016) Yüksek lisans tezi, Türkçe Eğitimi, Masalların yaratıcı yazma becerisine bir etkisinin olup

Adres | Address

RumeliDE Dil ve Edebiyat Arașturmaları Dergisi Osmanağa Mahallesi, Mürver Ciceği Sokak, No:14/8 Kadıköy - ISTANBUL / TÜRKIYE 34714 e-posta: editor@rumelide.com tel: +90 505 7958124, +90 2167730616
RumeliDE Journal of Language and Literature Studies

Osmanağa Mahallesi, Mürver Çiçeği Sokak, No:14/8

Kadıköy - ISTANBUL / TURKEY 34714

e-mail: editor@rumelide.com

phone: +90 $5057958124,+902167730616$ 
olmadığı incelenmek

33. Dalkılıç-Fer (2017) Yüksek lisans tezi, Eğitim Bilimleri Anabilim Dalı, Hali hazırda yapılmakta ve uygulanmakta olan yaratıcı yazı çalışmalarını incelemek

34. Oğuz, (2017) Yüksek lisans tezi, Türkçe Eğitimi, Masalların birleştirilmesi yoluyla yaratıcı yazmanın ortaokul öğrencilerinin yazma becerisine katkısını ve öğrencilerin yaratıcılıklarına etkisini incelemek

35. Dolmaz (2017) Doktora tezi, Sosyal Bilgiler Eğitimi, Tarihsel romanların yaratıcı yazma becerilerine etkisini tespit etmek

36. Karadă̆ (2018) Yüksek lisans tezi, Türkçe Eğitimi, Storybird uygulamasının yaratıcı yazma becerisine ve yazmaya yönelik tutuma etkisini araştırmak

37. Dorlay (2018) Yüksek lisans tezi, Türkçe Eğitimi, $5 \mathrm{E}$ öğrenme modeline uygun yaratıcı yazma etkinliklerinin öğrencilerin yazma becerilerine olan etkisini araştırmak

38. Demirbaş (2019) Yüksek lisans tezi, Sınıf Eğitimi, Dijital öykülerin öğrencilerin yaratıcı yazma ve dinlediğini anlama becerileri üzerindeki etkisini belirlemek

39. Uslu (2019) Yüksek lisans tezi, Sınıf Eğitimi, İşbirlikli dijital hikâye anlatımının öğrencilerin yaratıcı yazma ve sosyal duygusal öğrenme becerilerine etkisini belirlemek

40. Erdoğan (2019) Yüksek lisans tezi, Sınıf Eğitimi, Türkçe dersinde yansıtıcı düşünme destekli yaratıcı yazma çalışmalarının öğrencilerin yaratıcı yazma becerilerine etkisini belirlemek

41. Et (2019) Yüksek lisans tezi, Türkçe Eğitimi, Karikatür destekli yazma çalışmalarının yaratıcı yazma becerisinin gelişimindeki etkisini incelemek

42. Kalaç (2019) Yüksek lisans tezi, Türkçe Eğitimi, Klasik Türk şiiri çeviri örneklerinden yararlanarak öğrencilerin yaratıcı yazma becerilerini geliştirmek

43. Uluyüz, (2019) Yüksek lisans tezi, Türkçe Eğitimi, Alternatif dinleme/izleme materyallerinin ortaokul ögrencilerinin yaratıcı yazma becerilerine etkisini tespit etmek

44. Yılmaz (2019) Yüksek lisans tezi, Türkçe Eğitimi, Türk halk edebiyatı unsurlarının Türkçe öğretiminde kullanımının yaratıcı yazmaya etkisini saptamak

45. Uç (2019) Yüksek lisans tezi, Fen Eğitimi, Yazma destekli argümantasyon uygulamalarının öğrencilerin yazma öz yeterliklerine, yaratıcı yazmalarına ve kavram öğrenmelerine etkisinin olup olmadığı incelemek

46. Özdemir (2010) Yüksek lisans tezi, Türkçe Eğitimi, Üstün yetenekli öğrencilerle normal öğrencilerin yaratıcı yazma çalışmalarının düzeylerini tespit etmek

47. Saluk (2017) Yüksek lisans tezi, Türkçe Eğitimi, Yaratıcı yazma etkinliklerinin üstün yeteneklilerin yazma tutumu üzerindeki etkisini tespit etmek ve yaratıcı yazma becerilerini geliștirmek

48. Bayer (2019) Yüksek lisans tezi, Fizik Ĕgitimi, Yaratıcı yazma etkinlikleri kullanarak öğrencilerin fizik ile ilgili bilgi ve kavrayışlarını ortaya çıkarmak

49. Bulut (2012) Yüksek lisans tezi, Türkçe Eğitimi, 2006 Türkçe Dersi Öğretim Programındaki yazma kazanımlarının yaratıcı yazmaya uygunluğunu incelemek

50. Uyğun (2019) Yüksek lisans tezi, Türkçe Eğitimi, 2018 Türkçe Dersi Öğretim Programında yer alan yazma kazanımlarının ve Türkçe ders kitaplarındaki yazma etkinliklerinin yaratıcı yazma becerisine uygunluk durumunu tespit etmek

51. Aydın (2020) Yüksek lisans tezi, Türkçe Eğitimi, Yaratıcı düşünmenin yaratıcı yazmaya etkisini ortaya koymak

Bu bölümde tezlerin hipotezlerinin tematik analizi yer almaktadır.

Tutum (bk. Tablo 2) 17 tezde tutum incelenmiştir. 12 tez yazmaya yönelik tutumu (sıra 6, 8, 12, 14, 15, 19, 23, 24, 27, 30, 36, 47) incelemektedir. 4 tez derse yönelik tutumu (sıra 1, 3, 13, 19) incelemektedir. 1 tez yaratıcı yazmaya yönelik tutumu (sıra 22) incelemektedir. Bunların yanı sıra 6 tez yazma eğilimi (sıra 10, 11), yazma öz yeterlikleri (sıra 9, 12, 45), yazma kaygısını (sıra 10) incelemiştir.

Yaratıcı yazma etkinliklerinin yazılı ifade becerisiyle korelasyonu (bk. Tablo 2) Bu başlık altında 13 tez bulunmaktadır. Tezlerden 8'i yaratıcı yazma etkinliklerinin yazma becerisi üzerindeki (sıra 6, 8, 12, 15, $16,19,20,30$ ) etkisine odaklanmıştır. Tezlerden 5 ’i yaratıcı yazma etkinliklerinin yaratıcı yazma becerisi üzerindeki (sıra 1, 6, 7, 19, 20) etkisine odaklanmıştır.

\footnotetext{
RumeliDE Dil ve Edebiyat Araștırmaları Dergisi Osmanağa Mahallesi, Mürver Ciçĕ̌i Sokak, No:14/8 Kadıköy - İSTANBUL / TÜRKIYE 34714 e-posta: editor@rumelide.com

Address

RumeliDE Journal of Language and Literature Studies Osmanağa Mahallesi, Mürver Çiçeği Sokak, No:14/8

Kadıköy - ISTANBUL / TURKEY 34714

e-mail: editor@rumelide.com,

tel: +90 505 7958124, +902167730616 phone: +90 505 7958124, +90 2167730616
} 
Çeşitli strateji veya unsurların yaratıcı yazma becerisiyle korelasyonu (bk. Tablo 2) Tezlerden 18’i çeşitli strateji veya unsurların yaratıcı yazma üzerindeki etkisini incelemektedir. Strateji veya unsurlar şöyledir: yaratıcı drama (sıra 23, 25, 26, 27), özel mülkiyet/yarım bırakılmış materyal tekniği (sıra 28), araştırmacı yazma (sıra 17) metinler arası okuma yaklaşımı (sıra 29), süreç temelli yazma modeli (sıra 30, 31), masallar (sıra 32), masalların birleştirilmesi (sıra 34), tarihsel romanlar (sıra 35), storybird uygulaması (sıra 36), 5E modelli (sıra 37), dijital hikâye (sıra 38), işbirlikli dijital hikâye (sıra 39), yansitıcı düşünme (sıra 40), karikatür (sıra 41), klasik Türk şiiri çeviri örnekleri (sıra 42), alternatif dinleme/izleme materyalleri (sıra 43), Türk halk edebiyatı unsurları (sıra 44), argümantasyon uygulamaları (sıra 45), yaratıcı düşünme (sıra 51).

Türkçe öğretim programları ve Türkçe ders kitapları (bk. Tablo 2) 1 tezde, 2006 öğretim programı, yaratıcı yazma becerisi açısından incelenmiş (sıra 49), 1 tezde 2018 öğretim programı ve Türkçe ders kitapları yaratıcı yazma açısından incelenmiştir (sıra 50). 1 tezde (sıra 51) yaratıcı düşünmenin yaratıcı yazmaya etkisini ortaya koymak amaçlanmış ancak doküman olarak Türkçe ders kitapları incelenmiştir.

\section{2. Çalışma deseni, katılımcılar ve süre bakımından analitik bakış}

Desen (bk. Tablo 3). Aynı desenler kullanılmış farklı tezlerde, yöntemlere farklı isimler verildiği görülebilmektedir (bakınız sıra 16, 18, 23). Tezlerde, en çok kullanılan desen, ön ve son testli yarı deneysel modeldir. 39 tezin yönteminde bu desen görülmektedir. Bu 39 tezin 13’ü “ön ve son testli yarı deneysel model + görüşme" kombinasyonuyla yürütülmüştür. 34 tezde kontrol grubu bulunmaktadır. 5 tezde ise tek grupla (sıra 1, 15, 26, 40, 42) çalışılmıştır. 6 tezin yönteminde doküman analizi deseni (sıra 2, 6, 46, 49, 50, 51) bulunmaktadır. Bunların dışında geri kalan tezlerde; betimsel araştırma modeli (sıra 33, 48), genel tarama modeli (sıra 2), anket-tarama modeli (sıra 4), ilişkisel tarama modeli (sıra 9), olgubilim (sıra 34), durum çalışması (sıra 50) desenleri kullanılmıştır.

Çalıșma grubu (bk. Tablo 3). Tezlerde en çok çalışılan gruplar sırasıyla dördüncü, yedinci ve beşinci sınıflardır. Sınıf düzeyine göre sayllar şöyledir: üçüncü sınıf (4 tez), dördüncü sinıf (10 tez), beşinci sinif (8 tez), altıncı sinif (4 tez), yedinci sinif (9 tez), sekizinci sinif (6 tez), dokuzuncu sinif (2 tez). Bunun yanı sıra orta okul düzeyi ile karma çalışılan 3 tez, lise düzeyi ile karma çalışılan 1 tez ve Türkçe Öğretmenliği 3.sınıf öğrencileri ile çalışılan 1 tez bulunmaktadır. Türkçe öğretim programını inceleyen 1 tez, Türkçe öğretim programları ile Türkçe ders kitaplarını bir arada inceleyen 2 tez bulunmaktadır.

Tablo 3. Çalışma deseni, katılımcılar ve süreye yönelik özet

\begin{tabular}{|c|c|c|c|}
\hline Çalışma & Desen & Süre & $\begin{array}{l}\text { Çalıssma } \\
\text { grubu }\end{array}$ \\
\hline Demirbaş (2005) & Ön test son test tek gruplu yarı deneysel model, Görüşme & & 9.sinif \\
\hline Maltepe (2008) & Karma: genel tarama modeli, doküman analizi & & 6., 7., 8. sinif \\
\hline Kapar Kuvanç (2008) & Ön test son test kontrol gruplu yarı deneysel model & 12 hafta & 5.sinif \\
\hline Kurbaş (2010) & Anket-tarama modeli & & 7.sinif \\
\hline Duran (2010) & - & - & - \\
\hline Beydemir (2010) & $\begin{array}{l}\text { Ön test son test kontrol gruplu yarı deneysel model, } \\
\text { doküman analizi }\end{array}$ & 11 hafta & 5.sinif \\
\hline Tonyalı (2010) & Ön test son test kontrol gruplu yarı deneysel model & 12 hafta & 6.sinif \\
\hline
\end{tabular}

\begin{tabular}{r|l} 
Adres & Address \\
RumeliDE Dil ve Edebiyat Araştırmaları Dergisi & RumeliDE Journal of Language and Literature Studies \\
Osmanağa Mahallesi, Mürver Çiçeği Sokak, No:14/8 & Osmanağa Mahallesi, Mürver Çiçeği Sokak, No:14/8 \\
Kadıköy - İSTANBUL / TÜRKIYE 34714 & Kadıköy - ISTANBUL / TURKEY 34714 \\
e-posta: editor@rumelide.com & e-mail: editor@rumelide.com, \\
tel: +90 505 7958124, +90 2167730616 & phone: +90 505 7958124, +90 2167730616
\end{tabular}


An analytical analysis of theses about creative writing in Turkish education as a native language: A scoping review / S. Konuk (pp. 706-733)

$\operatorname{Ak}(2011)$

Demir (2011)

Avcl (2013)

Duru (2014)

Korkmaz (2015)

Başkök (2012)

Yüksel (2016)

Yıldırım (2018)

Akbaba (2020)

Taç (2020)

Karataş (2020)

Gökçe (2020)

Kasap (2019)

Karataş (2019)

Razgatlığlu (2020)

Türkel (2011)

Kılıç (2018)

Erdoğan (2018)

Duman-Yegen (2019)

İsbir-Abrekoşlu (2019)

Peker (2015)

Akdal (2011)

Erdoğan (2012)

Sever (2013)

Urhan (2016)

Dalkılıç-Fer (2017)

Oğuz, (2017)

Dolmaz (2017)

Karadağ (2018)

Dorlay (2018)

Demirbaş (2019)
Ön test son test kontrol gruplu yarı deneysel model

İlişkisel tarama modeli

Ön test son test kontrol gruplu yarı deneysel model

Ön test son test kontrol gruplu yarı deneysel model

Ön test son test kontrol gruplu yarı deneysel model

Ön test son test kontrol gruplu yarı deneysel model

Ön test son test kontrol gruplu yarı deneysel model

Eylem araştırması (tek grup ön ölçüm son ölçüm)

Karma: Ön test son test kontrol gruplu yarı deneysel model, Görüşme

Ön test son test kontrol gruplu yarı deneysel model

Eylem araştırması: Ön test son test ve kalıcılık testli ve kontrol gruplu yarı deneysel model, Görüşme

Ön test son test kontrol gruplu yarı deneysel model

Karma: Ön test son test kontrol gruplu yarı deneysel model, Görüşme

Ön test son test kontrol gruplu yarı deneysel model

Karma: Ön test son test kontrol gruplu yarı deneysel model

Ön test son test kontrol gruplu yarı deneysel model, Görüşme

Karma: Ön test son test kontrol gruplu yarı deneysel model, görüşme

Ön test son test kontrol gruplu yarı deneysel model

Eylem araştırması: Tek grup ön ölçüm ve son ölçüm, günlükler

Karma: Ön test son test kont
model, Odak grup görüşmesi

Ön test son test kontrol gruplu yarı deneysel model, odak grup görüşmesi

Ön test son test kontrol gruplu yarı deneysel model

Karma: Ön test son test kontrol gruplu yarı deneysel model, (üç grup), Görüşme

Ön test son test kontrol gruplu yarı deneysel model

Ön test son test kontrol gruplu yarı deneysel model

Betimsel araştırma modeli

Olgubilim

Karma: Ön test son test kontrol gruplu yarı deneysel model, Görüşme

Karma: Ön test son test kontrol gruplu yarı deneysel model, Görüşme

Ön test son test kontrol gruplu yarı deneysel model

Ön test son test kontrol gruplu yarı deneysel model

\begin{tabular}{|c|c|}
\hline 12 hafta & 5.sinif \\
\hline & 8.sinif \\
\hline 8 hafta & 8.sinif \\
\hline 9 hafta & 6.sinif \\
\hline 12 hafta & 6.sinif \\
\hline 12 hafta & 7.sinif \\
\hline 12 hafta & 5.sinif \\
\hline 10 hafta & $\begin{array}{l}\text { Türkçe } \\
\text { Ö ğretmenliği } \\
\text { 3. sinıf }\end{array}$ \\
\hline 8 hafta & 7.sinif \\
\hline 15 hafta & 3. sinif \\
\hline 13 hafta & 4.sinif \\
\hline 10 hafta & 4.sinif \\
\hline 14 hafta & 4.sinif \\
\hline 6 hafta & 4.sinif \\
\hline 18 hafta & 3. sinif \\
\hline 12 hafta & 8.sinif \\
\hline 7 hafta & 9.sinif \\
\hline 6 hafta & 4.sinif \\
\hline 10 hafta & 3. sinif \\
\hline 8 hafta & 7.sinif \\
\hline 12 hafta & 4.sinif \\
\hline 4 hafta & 5.sinif \\
\hline 16 hafta & $5 . \sin i f$ \\
\hline 8 hafta & 4.sinif \\
\hline 8 hafta & 8.sinif \\
\hline & 3. sinif \\
\hline 4 hafta & $5 \cdot 6.7 . \sin i f$ \\
\hline 12 hafta & 7.sinif \\
\hline 13 hafta & 5.sinif \\
\hline 8 hafta & 5.sinif \\
\hline 8 hafta & 4.sinif \\
\hline
\end{tabular}

Öğretmenliği

7.sinif

3. sinif

4.Sinif

4.Sinif

14 hafta 4.sinif

6 hafta 


\begin{tabular}{|c|c|c|c|}
\hline Uslu (2019) & Ön test son test kontrol gruplu yarı deneysel model & 11 hafta & 4.sinif \\
\hline Erdoğan (2019) & Ön test son test tek gruplu yarı deneysel model & 6 hafta & 4.sinif \\
\hline Et (2019) & Ön test son test kontrol gruplu yarı deneysel model & 7 hafta & 7.sinif \\
\hline Kalaç (2019) & Ön test son test tek gruplu yarı deneysel model & 5 hafta & 8.sinif \\
\hline Uluyüz, (2019) & Ön test son test kontrol gruplu yarı deneysel model & 8 hafta & 7.sinif \\
\hline Yllmaz (2019) & Nitel bir durum çalışması & & 8.sinif \\
\hline Uç (2019) & $\begin{array}{l}\text { Karma: Ön test son test kontrol gruplu yarı deneysel } \\
\text { model, görüşme }\end{array}$ & 7 hafta & 7.sinif \\
\hline Özdemir (2010) & $\begin{array}{l}\text { Nitel araştırma, öğrenci metinlerini doküman analiziyle } \\
\text { değerlendirme }\end{array}$ & & $\begin{array}{l}\text { 6., 7., 8. sinıf } \\
\text { (Üstün } \\
\text { yetenekli) }\end{array}$ \\
\hline Saluk (2017) & $\begin{array}{l}\text { Karma: Ön test son test kontrol gruplu yarı deneysel } \\
\text { model, Görüşme }\end{array}$ & 8 hafta & $\begin{array}{l}\text { 6.sinıf } \\
\text { (Üstün } \\
\text { yetenekli) }\end{array}$ \\
\hline Bayer (2019) & Betimsel araştırma, dokuman inceleme & & $\begin{array}{l}\text { Lise düzeyi } \\
\text { karma }\end{array}$ \\
\hline Bulut (2012) & Doküman analizi: 2006 Türkçe dersi öğretim programı & & $\begin{array}{l}17 \\
\text { akademisyen }\end{array}$ \\
\hline Uyğun (2019) & $\begin{array}{l}\text { Durum çalışması (Doküman incelemesi): Türkçe dersi } \\
\text { öğretim programı, Türkçe ders kitapları }\end{array}$ & & \\
\hline Aydın (2020) & $\begin{array}{l}\text { Doküman incelemesi: Türkçe dersi öğretim programı ve } \\
\text { ortaokul Türkçe ders kitapları }\end{array}$ & & \\
\hline
\end{tabular}

Süre (bk. Tablo 3). Tezlerde en çok tercih edilen uygulama süresi 12 hafta ve 8 haftadır. En çoktan ez aza doğru tercih edilen süreler şu şekildedir: 12 hafta (9 tez), 8 hafta (9 tez), 10 hafta (3 tez), 7 hafta (3 tez), 6 hafta ( 3 tez), 13 hafta ( 2 tez), 11 hafta ( 2 tez), 4 hafta ( 2 tez), 18 hafta ( 1 tez), 16 hafta ( 1 tez), 15 hafta ( 1 tez), 14 hafta (1 tez), 9 hafta ( 1 tez), 5 hafta (1 tez).

\section{Veri toplama araçları açısından analitik bakış}

Tezlerde, form, test, rubrik ve ölçek kavramlarının birbiri yerine kullanılabildiği görülmektedir ((bk. Tablo 4) Form ve ölçek kavramı için sıra 23, 25. Rubrik ve ölçek kavramı için sıra 41, 47). Tezlerdeki test, ölçek, rubrik araçları birlikte değerlendirildiğinde, 51 tezden 43’ünde, bu başlıklarda ölçme araçlarının kullanıldığı görülmektedir (bk. Tablo 4). 8 tezde bahsi geçen test, rubrik ve ölçek başlıklarında araçlar kullanılmamıştır. Tezlerden 28'inde, yazarın kendi tezinde test, rubrik ve ölçek başlıklarında kullandığı ölçme araçlarının tamamı farklı araştırmalardan hazır olarak alınmıştır (sıra 1, $6,10,11,12,13,14,15,19,21,23,24,25,26,27,9,31,32,35,36,37,38,39,41,42,43,46,47)$. Tezlerden 11'inde, yazarın kendi tezinde kullandığı test, rubrik ve ölçek ölçme araçlarının tamamını yazarın kendisi (YK) geliştirmiştir (sıra 2, 3, 16, 17, 18, 20, 30, 33, 34, 40, 50). Tezlerden 5’inde, test, rubrik ve ölçek ölçme araçlarının bazılarının farklı araştırmalardan hazır olarak alındığı bazılarının da yazarın kendisi tarafından geliştirdiği hibrit bir yapı vardır (sıra 7, 8, 9, 22, 45). 
Tablo 4. Veri toplama araçlarının özeti

\begin{tabular}{|c|c|}
\hline Çalışma & Veri toplama araçları \\
\hline Demirbaş (2005) & $\begin{array}{l}\text { Iraksak hissetme ölçeği "Williams" } \\
\text { Iraksak hissetme ölçeği "Williams" } \\
\text { Williams ölçeği "Williams" } \\
\text { Biyoloji tutum ölçeği “Binzat” } \\
\text { Yarı yapılandırılmış görüşme }\end{array}$ \\
\hline Maltepe (2008) & $\begin{array}{l}\text { Yazılı anlatım süreçlerini yaratıcı yazma yaklaşımı açısından değerlendirme ölçeği } \\
\text { (YK) } \\
\text { Kompozisyonlar }\end{array}$ \\
\hline Kapar Kuvanç (2008) & $\begin{array}{l}\text { Türkçe dersi başarı testi (YK) } \\
\text { Türkçe dersi tutum ölçeği (YK) } \\
\text { Yaratıcı yazma etkinlik yaprakları (YK) }\end{array}$ \\
\hline Kurbaş (2010) & $\begin{array}{l}\text { Anket (YK) } \\
\text { Kişisel bilgi formu (YK) } \\
\text { Öğrenci metinleri }\end{array}$ \\
\hline Duran (2010) & - \\
\hline Beydemir (2010) & $\begin{array}{l}\text { Yaratıcı yazma ürünlerini değerlendirme ölçeği "Susar-Kırmızı ve Beydemir” } \\
\text { Yazmaya yönelik tutum ölçeği "Susar-Kırmızı" } \\
\text { Yazma becerisi ölçeği “Uysal” } \\
\text { Beceri ölçeği formu (YK) } \\
\text { Anket-açık uçlu soru formu (YK) }\end{array}$ \\
\hline Tonyalı (2010) & $\begin{array}{l}\text { Yaratıcı yazma değerlendirme ölçeği (YK) } \\
\text { Torrance yaratıcı düşünce testi “Aslan” }\end{array}$ \\
\hline $\mathrm{Ak}(2011)$ & $\begin{array}{l}\text { Yaratıcı yazma için değerlendirme ölçütleri formu "Susar-Kırmızı" } \\
\text { Yazılı anlatıma yönelik tutum ölçeği (YK) }\end{array}$ \\
\hline Demir (2011) & $\begin{array}{l}\text { Yaratıcı yazma rubriği “Öztürk” } \\
\text { Kişisel bilgi formu “Bacanlı” } \\
\text { Yazma özyeterlik ölçeği (yazarın kendisi Türkçeye uyarladı YKU) } \\
\text { Başarı amaç yönelimi ölçeği (YKU) }\end{array}$ \\
\hline Avcl (2013) & $\begin{array}{l}\text { Yazma eğilimi ölçeği “İşeri ve Ünal” } \\
\text { Yazma kaygısı ölçeği “Özbay ve Zorbaz” }\end{array}$ \\
\hline Duru (2014) & $\begin{array}{l}\text { Yazma eğilimi ölçeği "İşeri ve Ünal” } \\
\text { Yazılı anlatım süreçlerini yaratıcı yazma yaklaşımı açısından değerlendirme ölçeği } \\
\text { "Maltepe" }\end{array}$ \\
\hline Korkmaz (2015) & $\begin{array}{l}\text { Yazmaya yönelik tutum ölçeği "Susar-Kırmızı" } \\
\text { Yazma öz yeterlikleri ölçeği "Şengül” } \\
\text { Yazılı anlatım değerlendirme formu “2006 Türkçe dersi öğretim programı” }\end{array}$ \\
\hline Başkök (2012) & $\begin{array}{l}\text { Alternatif kullanım testi “Christensen ve ark.” } \\
\text { Sözcük akıcılı̆̆ı testi “Christensen ve Guilford” } \\
\text { Düşünsel akıcılık testi “Christensen ve Guilford” } \\
\text { Sonuçlar testi Christensen ve ark.” } \\
\text { Türkçe dersi tutum ölçeği "Kapar-Kuvanç" }\end{array}$ \\
\hline Yüksel (2016) & $\begin{array}{l}\text { Alternatif kullanım testi “Christensen ve ark.” } \\
\text { Sözcük akıcılığı testi “Christensen ve Guilford” } \\
\text { Düşünsel akıcılık testi “Christensen ve Guilford” }\end{array}$ \\
\hline
\end{tabular}


Ylldırım (2018)

Akbaba (2020)

$\operatorname{Taç~(2020)~}$

Karataş (2020)

Gökçe (2020)

Kasap (2019)

Karataș (2019)

Razgatlığlu (2020)

Türkel (2011)

Kılıç (2018)

Erdoğan (2018)

Duman-Yegen (2019)

İsbir-Abrekoşlu (2019)

Peker (2015)
Sonuçlar testi "Christensen ve ark."

Yazmaya yönelik tutum ölçeği "Susar-Kırmızı"

Yazılı anlatım değerlendirme formu "2006 Türkçe dersi öğretim programı”

Yarı yapılandırılmış görüşme formu (YK)

Araștırmacı günlüğü

Öğrenci yazılı anlatım kâğıtları

Öyküleyici metin yazma becerisi değerlendirme formu (YK)

İleri okuma farkındalık ölçeği (YK)

Yarı yapılandırılmış görüşme formu (YK)

Araştırmacı yazma değerlendirme rubriği (YK)

Yaratıcı hikâye yazma rubriği (YK)

Akıcı hikâye yazma rubriği (YK)

Yaratıcı hikâye yazma ürününü puanlama anahtarı (YK)

Görüşme formu (YK)

Yaratıcı yazma değerlendirme formu "Susar-Kırmız”"

Yazmaya yönelik tutum ölçeği "Susar-Kırmızı"

Türkçe dersi tutum ölçeği "Ünal ve Köse”

Yaratıcı okuma sürecini değerlendirme ölçeği (YK)

Okuduğunu anlama testi (YK)

Yazma ürünlerini değerlendirme ölçeği (YK)

Yaratıcı yazma ürünlerini değerlendirme ölçeği (YK)

Yarı yapılandırılmış görüşme formları (YK)

Sorumluluk ölçeği “Abdi Golzar”

Prozodik okuma ölçeği "Ulusoy ve ark.”

Şiir yazma rubriği (YK)

Şiirlere yönelik tutum ölçeği (YK)

Okuma hızı kayıt çizelgesi (YK)

Okuma doğruluğu kayıt çizelgesi (YK)

Prozodi kayıt çizelgesi (YK)

Yanlış analizi envanteri (YK)

Yarı yapılandırılmış görüşme formu (YK)

Yaratıcı yazma ürünlerini değerlendirme ölçeği "Susar-Kırmızı"

Yazmaya yönelik tutum ölçeği "Susar-Kırmızı"

Görüşme formu (YK)

Yazma tutum ölçeği “Akaydın ve Kurnaz”

Yarı yapılandırılmış görüşme formu (YK)

Yaratıcı yazma için değerlendirme ölçütleri formu "Susar-Kırmızı"

Yaratıcı yazma rubriği "Öztürk"

Yanlış analizi envanteri (YK)

Öğrenci, öğretmen, veli görüşmeleri

Öz değerlendirme formları (YK)

Öğrenci, veli ve öğretmen günlükleri

Yaratıcı yazma ürünlerini değerlendirme ölçeği "Susar-Kırmızı ve Beydemir" Yazmaya yönelik tutum ölçeği "Susar-Kırmızı"

Görüşme formu (YK)

Ön ölçüm (YK)

\footnotetext{
Adres $\mid$ Address

RumeliDE Dil ve Edebiyat Araşttrmalar Dergisi Osmanağa Mahallesi, Mürver Çiçeği Sokak, No:14/8

Kadıköy - İSTANBUL / TÜRKIYE 34714 e-posta: editor@rumelide.com

tel: +90 $5057958124,+902167730616$

RumeliDE Journal of Language and Literature Studies

Osmanağa Mahallesi, Mürver Çiçeği Sokak, No:14/8

Kadıköy - ISTANBUL / TURKEY 34714

e-mail: editor@rumelide.com,

phone: +90 505 7958124, +90 2167730616
} 
Akdal (2011)

Erdoğan (2012)

Sever (2013)

Urhan (2016)

Dalkılıç-Fer (2017)

Oğuz, (2017)

Dolmaz (2017)

Karadağ (2018)

Dorlay (2018)

Demirbaş (2019)

Uslu (2019)

Erdoğan (2019)

Et (2019)

Kalaç (2019)

Uluyüz, (2019)

Yllmaz (2019)

Uç (2019)

Özdemir (2010)

Saluk (2017)
Son ölçüm (YK)

Görüşme soruları (YK)

Yaratıcı yazma rubriği "Öztürk”

Yazma tutum ölçeği (YK)

Yazılı anlatımı değerlendirme için derecelendirilmiş puanlama anahtarı (YK)

Öğrenci ve öğretmen görüşme formları (YK)

Yaratıcı yazma ürünlerini değerlendirme ölçeği "Susar-Kırmızı" 4+1 planlı yazma ve değerlendirme ölçeği "Karatay" 6+1 analitik yazma ve değerlendirme ölçeği "Özkara"

Yaratıcı yazma rubriği "Öztürk”

Yaratıcıllk testi (YK)

Yaratıcı yazma becerilerini değerlendirme kontrol listesi (YK)

Yaratıcı yazma rubriği "Öztürk”

Yaratıcı yazma çalışma yaprağı (YK)

Görüşme formu (YK)

Yaratıcı yazma ürünleri değerlendirme ölçeği "Susar-Kırmızı"

Yazmaya yönelik tutum ölçeği "Can ve Topçuoğlu-Ünal”

Görüşme formları (YK)

Yaratıcı yazma rubriği "Öztürk”

Yaratıcı yazma rubriği "Öztürk”

Dinlediğini anlama testi "Bulut"

Hikâye haritası (YK)

Yaratıcı yazma rubriği "Öztürk"

Sosyal duygusal öğrenme, becerileri ölçeği "Kabakçı ve Owen”

Katılımcı bilgi formu (YK)

Yaratıcı yazma değerlendirme rubriği (YK)

Yansitıcı düşünme günlükleri

Yaratıcı yazma rubriği "Öztürk”

Yaratıcı yazma için değerlendirme ölçütleri formu "Susar-Kırmızı"

Yaratıcı yazma konularını değerlendirme ölçütleri "Özdemir"

Dinleme kaygısı ölçeği "Melanlığlu"

Dinlemeye yönelik tutum ölçeği "Özbay ve ark."

Kişisel bilgi formu (YK)

Anket-açık uçlu anket formu (YK)

Çalışma kâğıtları (YK)

Yaratıcı yazma ürünlerini değerlendirme ölçeği "Susar-Kırmızı ve Beydemir" Yazma öz yeterlikleri ölçeği "Şengül”

Argüman raporu değerlendirme Rubriği "Cope ve ark”

Kavram öğrenme testi (YK)

Yarı yapılandırılmış görüşme formu (YK)

Yazma için çözümleyici puanlama yönergesi “Arı”

Yaratıcı yazma ölçeği "Öztürk”

Yazmaya yönelik tutum ölçeği "Susar-Kırmızı"

Görüşme formu (YK)

Ön test-son test yazma konuları

\footnotetext{
Adres

RumeliDE Dil ve Edebiyat Arasttrmalar Dergisi Osmanağa Mahallesi, Mürver Çiçeği Sokak, No:14/8

Kadıköy - İSTANBUL / TÜRKIYE 34714

e-posta: editor@rumelide.com

tel: +90 $5057958124,+902167730616$

Address

RumeliDE Journal of Language and Literature Studies

Osmanağa Mahallesi, Mürver Çiçeği Sokak, No:14/8

Kadıköy - ISTANBUL / TURKEY 34714

e-mail: editor@rumelide.com,

phone: +90 505 7958124, +90 2167730616
} 


$\begin{array}{ll}\text { Bayer (2019) } & \text { Anket (YK) } \\ \text { Bulut (2012) } & \text { Anket (YK) } \\ \text { Uyğun (2019) } & \text { Yaratıcı yazmaya uygunluk değerlendirme formu (YK) } \\ \text { Aydın (2020) } & -\end{array}$

Tablo notu: (YK)=Yazarın kendisi. (YKU)=yazarın kendisi Türkçeye uyarladı. Tabloda yer alan ifadeler tez yazarlarına aittir. Tabloda bulunan ölçme araçlarına ve sahiplerine ilişkin bilgiler tezlerin içeriğine yönelik yazılı veriler olduğundan ve bu araştırmanın konusuyla doğrudan ilgisi olmadığından kaynakçada yer verilmemiştir.

Yaratıcı yazmayı değerlendirme (bk. Tablo 4). Tezlerden 3o'unda, yaratıcı yazma becerisi için değerlendirme araçları kullanılmıştır. Tezlerde, yaratıcı yazmayı değerlendirmek üzere 12 farklı değerlendirme aracı kullanılmış olup bunların 8'ini yazarın kendisi (sıra 2, 7, 17, 18, 20, 34, 40, 50) geliştirmiştir. Diğer 22 tezde, aynı ölçme araçlarının tekrarlı kullanımları görülmektedir. Tezlerden 10’unda, bir araştırmacının geliştirdiği aynı ölçme aracı (sıra 9, 26, 29, 32, 35, 37, 38, 39, 41, 47), tezlerden 10'unda farklı bir araştırmacının geliştirdiği aynı ölçme aracı (sıra 6, 8, 19, 23, 25, 27, 31, 36, 42, 45) kullanılmıştır.

Yazılı anlatım becerisini değerlendirme (bk. Tablo 4). Tezlerden 11'inde çeşitli yazma becerilerini değerlendirilmiştir. 10 farklı değerlendirme aracı kullanılmıştır. Bu araçlardan 5’i yazar tarafından (sıra 16, 17, 20, 30) geliştirilmiş, $5 ’ \mathrm{i}$ (sıra 6, 12, 15, 31, 46) hazır olarak farklı araştırmalardan alınmıştır.

Yazmaya yönelik tutum (bk. Tablo 4). Tezlerden 11'inde, yazmaya yönelik tutum ölçeği kullanılmıştır. 5 farklı ölçek bulunmaktadır. Ölçeklerden 2'si yazarın kendisi tarafından (sıra 8, 30) geliştirilmiş, 3'ü hazır olarak alınmıştır. Tezlerden 7'sinde bir araştırmacının geliştirdiği yazmaya yönelik tutum ölçeği (sıra 6, 12, 14, 19, 23, 27, 47) kullanılmıştır. Birer tezde de farklı araştırmacıların geliştirdiği iki farklı ölçek (sıra 19, 24) kullanılmıştır.

Yazma yetkinliklerine yönelik tutum (bk. Tablo 4). Tezlerde, yazma ile ilgili tutum ölçeklerinin yanı sıra yazma eğilimi ölçeği (sıra 10, 11), yazma öz yeterlikleri ölçeği (sıra 9, 12, 45), yazma kaygısı ölçeği 1 (sıra 10) kullanılmıştır. Bu başlık altında 4 farklı ölçek bulunmaktadır. Bunlardan sadece 1 tanesi yazarın kendisi tarafından (sıra 9) geliştirilmiştir.

Türkçe dersi tutum ölçeği (bk. Tablo 4). Tezlerden 3’inde Türkçe dersi tutum ölçeği kullanılmıştır. Bu tezlerden sadece 1’inde ölçek yazarın kendisi (sıra 3) tarafından geliştirilmiştir. Diğer ikisinde farklı araştırmacıların geliştirdiği iki ayrı ölçek $($ sıra 13, 19) kullanılmıştır.

\section{Temel sonuçlar bakımından analitik bakış}

Tutum (bk. Tablo 5). Tezlerden 9'unda, yaratıcı yazma etkinliklerinin yazma tutumuna etkisi incelenmiştir. Bu tezlerden 8'inde yaratıcı yazma etkinliklerinin yazmaya karşı öğrencilerin olumlu tutum geliştirmesini (sıra 6, 8, 12, 14, 15, 19, 30, 36) sağladığı sonucuna, tezlerden 1'nde bu etkinliklerin yazmaya karşı tutumu etkilemediği (sıra 47) sonucuna ulaşılmıştır. Olumlu tutum geliştirme sonucuna ulaşılan tezlerde normal öğrencilerle, 47. sıradaki tezde ise üstün zekalı öğrencilerle çalışılmıştır. Tezlerden 3’ünde yaratıcı drama etkinliklerinin yazmaya karşı tutumu geliştirdiği (sıra 23, 24, 27) sonucuna ulaşılmıştır. Yaratıcı yazma etkinliklerinin ders tutumuna etkisini inceleyen 4 tezden 3 'ünde öğrencilerin derse yönelik tutumu olumlu yönde (sıra 1, 3, 13, 19)

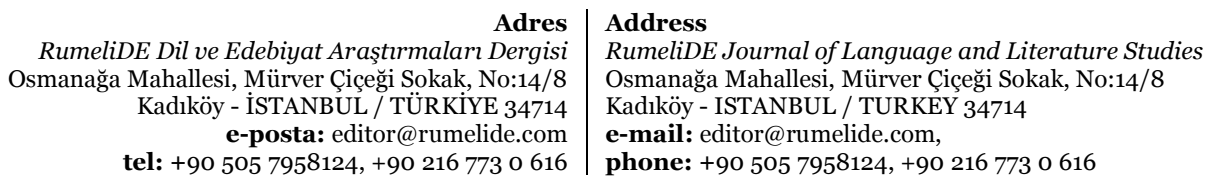


An analytical analysis of theses about creative writing in Turkish education as a native language: A scoping review / S. Konuk (pp. 706-733)

etkilenmiştir, sadece 1 tezde etkinliklerin derse karşı tutumda olumlu bir değişiklik olmadığı görülmüştür, o ders de biyoloji dersi olduğundan sonuç olağandır. Tezlerden 1'inde yaratıcı yazma etkinliklerinin öğrencilerin yazma eğilimleri üzerinde olumlu etkisi olduğu (sıra 10), başka bir tezde anlamlı bir etkisi olmadığı (sıra 11) sonucuna ulaşıldı. Tezlerden 2'sinde yaratıcı yazma ile yazma özyeterlik algısı arasında olumlu yönde (sıra 9, 12) ilişki olduğu tespit edilmiştir. Tezlerden 1’inde yaratıcı yazma etkinliklerinin öğrencilerin yazma kaygıları üzerinde anlamlı bir etkiye sahip olmadığı sonucuna ulaşılmıştır.

Tablo 5. Temel sonuçların özeti

\begin{tabular}{|c|c|}
\hline Çalışma & Temel sonuçlar \\
\hline \multirow[t]{2}{*}{ Demirbaş (2005) } & $\begin{array}{l}\text { Yaratıcı yazı etkinlikleriyle zenginleştirilen biyoloji dersinin öğrencilerin biyoloji dersi } \\
\text { akademik başarılarında ve derse karşı tutumlarında olumlu bir değişim sağlamadığı } \\
\text { belirlendi. }\end{array}$ \\
\hline & $\begin{array}{l}\text { Öğrencilerin önceki ve sonraki yaratıcılık düzeyi ve yaratıcı yazma becerilerinin } \\
\text { karşlaştırılması sonucunda anlamlı bir fark olmadığı sonucuna ulaşıldı. }\end{array}$ \\
\hline \multirow[t]{2}{*}{ Maltepe (2008) } & $\begin{array}{l}\text { Türkçe derslerindeki uygulamaların öğrencileri yaratıcı yazıma yöneltebilecek yazmaya } \\
\text { hazırlı süreçlerini ve yazılanları değerlendirme ve sunma süreçlerini yeterince } \\
\text { içermediği bulundu. }\end{array}$ \\
\hline & $\begin{array}{l}\text { Öğrencilerin, yazılarında düşünsel yaratıcılık açısından genellikle değişime kapalı ve } \\
\text { aktarmacı bir düşünce yapısı sergiledikleri bulundu. }\end{array}$ \\
\hline
\end{tabular}

Kapar Kuvanç (2008) Yaratıcı yazma teknikleri, öğrencilerin Türkçe dersine ilişkin olumlu tutumlarını artırdı.

Yaratıcı yazma teknikleri, akademik başarı üzerinde farklılık yaratmadı.

Yaratıcı yazma etkinlikleri öğrencilerin söz varlığını geliştirdi.

Kırbaş (2010) Yaratıcı yazma çalışmalarında "plânlama”, “yazım kurallarına uygun olarak yazma”, "noktalama işaretlerini doğru ve eksiksiz kullanma” davranışlarının kazanılmasında eksiklikler olduğu tespit edildi.

Duran (2010) Yaratıcı yazma tekniklerine uygun hazırlanan etkinlikler, öğrencilerin yazma becerilerinin gelişimini olumlu etkilendi.

Beydemir (2010) Yaratıcı yazma yaklaşımı, yazmaya yönelik tutumu ve yazma erişişine ulaşmayı olumlu yönde etkiledi.

Tonyalı (2010) Yaratıcı yazma etkinlikleri, öğrencilerin yaratıcı yazma becerilerinde anlamlı bir fark oluşturmadı ancak öğrencilerin yaratıcı düşünme becerisini geliştirdi.

Ak (2011) Yaratıcı yazma teknikleri, öğrencilerinin Türkçe dersindeki yazılı anlatım becerilerini ve yazılı anlatıma yönelik tutumlarını geliştirdi

Demir (2011) Yazma konunun serbest bırakılması yaratıcılı̆̆ı artırdı. Yaratıcı yazma ile yazma özyeterlik algısı arasında olumlu yönde, yaratıcı yazma ile performans amaç yönelimleri ve öğrenme amaç yönelimleri arasında olumlu yönde, yazma özyeterlik algısıyla performans amaç yönelimi ve öğrenme amaç yönelimi arasında olumlu yönde ilişki bulunuyor.

Avcı (2013) Yaratıcı yazma etkinliklerinin deney grubu öğrencilerinin yazma eğilimlerinde anlamlı fark oluşturduğu fakat yazma kaygılarında anlamlı fark oluşturmadı̆̆ı belirlendi.

Duru (2014) Yaratıcı yazma etkinliklerinin, öğrencilerin yazılı anlatım süreçlerini yaratıcı yazma yaklaşımı açısından değerlendirme düzeylerine geleneksel yöntemden daha çok etki sağladığı, yazma eğilimi açısından ise olumlu etki sağlamadığı bulundu.

Korkmaz (2015) Yaratıcı yazma, öğrencilerin yazma öz yeterlik algılarını, yazmaya yönelik tutumlarını ve yazma becerisi akademik başarılarını anlamlı düzeyde arttırdı

Başkök (2012) Yaratıcı yazma etkinliklerinin öğrencilerin Türkçe dersine yönelik tutumları üzerinde olumlu etkisi bulundu

Yüksel (2016) Yaratıcı yazma etkinliklerinin öğrencilerin yazmaya yönelik tutumları üzerinde olumlu etkisi, sözel yaratıcılıkları üzerinde anlamlı bir etkisi sonucuna ulaşıldı

\begin{tabular}{r|l} 
Adres & $\begin{array}{l}\text { Address } \\
\text { RumeliDE Dil ve Edebiyat Araşttrmalar Dergisi }\end{array}$ \\
RumeliDE Journal of Language and Literature Studies \\
Osmanağa Mahallesi, Mürver Çiçeği Sokak, No:14/8 & Osmanağa Mahallesi, Mürver Çiçeği Sokak, No:14/8 \\
Kadıköy - İSTANBUL / TÜRKIYE 34714 & Kadı̈öy - ISTANBUL / TURKEY 34714 \\
e-posta: editor@rumelide.com & $\begin{array}{l}\text { e-mail: editor@rumelide.com, } \\
\text { phone: +90 505 7958124, +90 216 } 773 \text { o } 616\end{array}$
\end{tabular}


Yıldırım (2018)

Akbaba (2020)

Taç (2020)

Karataş (2020)

Gökçe (2020)

Kasap (2019)

Karataş (2019)

Razgatlığlu (2020)

Türkel (2011)

Kılıç (2018)

Erdoğan (2018)

Duman-Yegen (2019)

İsbir-Abrekoşlu (2019)

Peker (2015)

Akdal (2011)

Erdoğan (2012)

Sever (2013)

Urhan (2016)

Dalkılıç-Fer (2017)

Oğuz, (2017)

Dolmaz (2017)

Karadağ (2018)

Dorlay (2018)

Demirbaş (2019)

Uslu (2019)

Erdoğan (2019)
Yaratıcı yazma etkinlikleri, Türkçe öğretmeni adaylarının yazmaya karşı tutumunu olumlu yönde etkiledi ve yazma becerisini geliştirdi.

Yaratıcı yazma süreci yazma, öyküleyici metin yazma ve okuma becerisi ile ileri okuma farkındalığını geliştirdi.

Araştırmacı yazma yaklaşımı akıcı ve yaratıcı yazma becerilerini geliştirdi.

Uygulama, öğrencilerin yaratıcı hikâye yazma becerilerinin gelişimine katkı sağladı.

Yaratıcı yazma uygulamaları, öğrencilerin Türkçe dersi tutumlarına ve yazma tutumlarına olumlu etki etti, yaratıcı yazma becerilerini geliştirdi.

Yaratıcı okuma, yaratıcı yazma uygulamaları, öğrencilerin yaratıcı okuma, okuduğunu anlama, yazma ve yaratıcı yazma erişilerinin anlamlı bir artış göstermesini sağladı.

Sorumluluk değerinin yaratıcı yazma teknikleri ile kazandırılmasının öğrencilerin sorumluluk düzeylerini artırdı ve yaratıcı yazı tekniklerini sorumluluk değerini kazandırmada oldukça etkili oldu.

Etkinlik temelli şiir çalışmalarının öğrencilerin yaratıcı yazma becerilerini geliştirmede etkili oldu ve yaratıcı yazmaya yönelik tutumlarının olumlu yönde etkiledi.

Yaratıcı drama yaratıcı yazma başarısını ve yazmaya karşı tutuma olumlu yönde etkiledi

Drama yöntemine dayalı yaratıcı yazma çalışmaları öğrencilerin yazma tutumunu olumlu etkiledi.

Yaratıcı drama yönteminin yaratıcı yazma becerisi üzerinde olumlu yönde etkisi olduğu sonucu bulundu.

Yaratıcı drama yönteminin, yaratıcı yazma becerisinin gelişimini sağladı ve öğrencilerin yazma isteğini artırdı.

Yaratıcı drama ile yaratıcı yazma öğretimi yaratıcı yazma becerilerini arttırmakta ve yazmaya yönelik tutumlarını geliştirmektedir.

Öğrencilerin yaratıcı yazma becerilerini geliștirmek için özel mülkiyet/yarım bırakılmıș materyal tekniğinin kullanılmasının faydalı olacağı sonucuna ulaşıldı.

Metinler arası okuma yaklaşımı yaratıcı yazma becerilerini geliştirdi.

Yaratıcı yazma ve işbirlikli yaratıcı yazma, öğrencilerin yazılı anlatım becerilerinin ve yazmaya ilişkin tutumlarının olumlu yönde geliştirdi.

Yaratıcı yazma becerileri son test ortalamaları karşılaştırıldığında 4+1 planlı yazma değerlendirme modeline göre düzenlenen yazma çalışmalarının öğrencilerin yazılı anlatım becerilerini olumlu yönde geliştirici bir etkiye sahip olduğu bulundu.

Masalların yaratıcı yazma ve yazılı iletişim becerilerine belirgin katkıları olduğu sonucuna varıldı.

Yaratıcı yazma başarısının hazır bulunuşluğa bağlı olduğu bulundu.

Masal birleştirme yoluyla yaratıcı yazma uygulamaları, katılımcıların yaratıcılıklarına olumlu katkı sağladı.

Farklı kurgu biçimlerine sahip tarihsel romanlar, öğrencilerin yaratıcı yazma becerilerini farklı düzeyde geliştirdi.

Storybird uygulaması, yaratıcı yazma becerilerini geliştirdi ve öğrencilerin yazmaya yönelik olumlu tutum geliştirimlerini sağladı.

5E modeli öğrencilerin yaratıcı yazma becerilerini artırmada önemli bir etkiye sahiptir.

Dijital öyküler öğrencilerin dinlediğini anlama ve yaratıcı yazma başarı puanlarını arttirdl.

İşbirlikli dijital hikâye hazırlamanın yaratıcı yazma becerilerini anlamlı bir şekilde arttırdı, sosyal duygusal öğrenme becerilerini ise anlamlı bir şekilde arttırmadı.

Yansıtıcı düşünme destekli yaratıcı yazma çalışmaları, yaratıcı yazma becerilerini geliştirdi.

\begin{tabular}{r|l} 
Adres & $\begin{array}{l}\text { Address } \\
\text { RumeliDE Dil ve Edebiyat Araştırmaları Dergisi }\end{array}$ \\
RumeliDE Journal of Language and Literature Studies \\
Osmanağa Mahallesi, Mürver Çiçeği Sokak, No:14/8 & Osmanağa Mahallesi, Mürver Çiç̧̧i Sokak, No:14/8 \\
Kadıköy - İSTANBUL / TÜRKIYYE 34714 & Kadıköy - ISTANBUL / TURKEY 34714 \\
e-posta: editor@rumelide.com & e-mail: editor@rumelide.com, \\
phone: +90 505 7958124, +90 2167730616
\end{tabular}


An analytical analysis of theses about creative writing in Turkish education as a native language: A scoping review / S. Konuk (pp. 706-733)

Et (2019)

Kalaç (2019)

Uluyüz, (2019)

Yllmaz (2019)

Uç (2019)

Özdemir (2010)

Saluk (2017)

Bayer (2019)

Bulut (2012)

Uyğun (2019)

Aydin (2020)

Karikatür destekli yazma çalışmaları yaratıcı yazma becerisini geliştirdi.

Klasik şiir çeviri örnekleri, öğrencilerin yaratıcı yazma becerilerine olumlu yönde katkı sağladı.

Alternatif dinleme/izleme materyalleri ortaokul öğrencilerinin yaratıcı yazma becerilerini geliştirdi ve dinleme kaygılarını azalttı.

Türk halk edebiyatı unsurları kullanılarak ders işlemek, öğrencilerin yaratıcı yazma becerisine katkı sağladı.

Yazma destekli argümantasyon uygulamaları yaratıcı yazmayı ve kavram öğrenmeyi olumlu yönde etkiledi, öğrencilerinin yazma öz yeterlikleri arasında anlamlı fark bulunmadi.

Normal öğrenciler üstün yetenekli öğrencilere göre biçim ve paragraf konusunda daha başarılı oldukları, üstün yetenekli öğrencilerin yazım kuralları, sözcük, cümle, anlatım, başlık, serim, düğüm ve çözüm bölümlerinde daha başarılı oldukları tespit edildi.

Yaratıcı yazma etkinlikleri deney grubunun yaratıcı yazma becerileri geliştirdi, ancak bu etkinlikler öğrencilerin yazmaya karşı tutumlarını değiştirmedi.

Yaratıcı yazma etkinlikleri, fiziğe yönelik öğrencilerin görüşlerini belirlemede etkili oldu.

Programda yer alan 42 yazma kazanımından 10 tanesi yaratıcı yazmaya uygundu.

2018 Türkçe Dersi Öğretim Programında yer alan 28 yazma kazanımı sınırlı bir kısmı ve Türkçe ders kitaplarında yer alan 185 yazma etkinliğinden 78 'i yaratıcı yazma becerisini geliştirmeye uygundu.

Ders kitaplarında yaratıcı yazma etkinliklerine yeterli düzeyde yer verilmediği tespit edildi.

Yaratıcı yazma etkinliklerinin yazılı ifade becerisiyle korelasyonu (bk. Tablo 5). Yaratıcı yazma etkinliklerinin yazma becerisi üzerindeki etkisine odaklanan 8 tezin tamamında yaratıcı yazma etkinliklerinin yazma becerisi üzerinde olumlu bir etkiye (sıra $6,8,12,15,16,19,20$, 30) sahip olduğu sonucuna ulaşılmıştır. Yaratıcı yazma etkinliklerinin yaratıcı yazma becerisi üzerindeki etkisine odaklanan 5 tezin 2'sinde yarıcı yazma etkinlikleri, öğrencilerin yaratıcı yazma becerilerinde anlamlı bir fark oluşturmamıştır (sıra 1, 7). Tezlerden 3 'ünde ise yaratıcı yazma etkinliklerinin yaratıcı yazmayı geliştirdiği sonucuna ulaşılmıştır (sıra 6,19, 20).

Çeşitli strateji veya unsurların yaratıcı yazma becerisiyle korelasyonu (bk. Tablo 5). Çeşitli strateji veya unsurların yaratıcı yazma üzerindeki etkisini inceleyen 18 tezin tamaminda strateji ve unsurların öğrencilerin yaratıcı yazma becerisi olumlu yönde geliştirdiği görülmüştür. Özetle yaratıcı drama (sıra 23, 25, 26, 27), özel mülkiyet/yarım bırakılmış materyal tekniği (sıra 28), metinler arası okuma yaklaşımı (sıra 29), süreç temelli yazma modeli (sıra 30, 31), masallar (sıra 32), masalların birleştirilmesi (sıra 34), tarihsel romanlar (sıra 35), storybird uygulaması (sıra 36), 5 E modeli (sıra 37), dijital hikâye (sıra 38), işbirlikli dijital hikâye (sıra 39), yansıtıcı düşünme (sıra 40), karikatür (sıra 41), klasik Türk şiiri çeviri örnekleri (sıra 42), alternatif dinleme/izleme materyalleri (sıra 43), Türk halk edebiyatı unsurları (sıra 44), argümantasyon uygulamaları (sıra 45) yaratıcı yazma becerisini olumlu yönde geliştirmiştir.

Türkçe öğretim programları ve Türkçe ders kitapları (bk. Tablo 5). 1 tezde 2006 Türkçe öğretim programındaki 42 yazma kazanımından 10 tanesi yaratıcı yazmaya uygun bulunmuş (sıra 49), 1 tezde 2018 Türkçe öğretim programındaki 28 yazma kazanımı sınırlı bir kısmı ve Türkçe ders kitaplarında yer alan 185 yazma etkinliğinden 78'i yaratıcı yazmayı geliştirmeye yönelik olduğu bulunmuştur (sıra 50). Bir yıl sonra, farklı 1 tezde de Türkçe ders kitaplarında, yaratıcı yazma etkinliklerine yeterli düzeyde yer verilmediği sonucuna ulaşılmıştır (sıra 51).

\footnotetext{
Adres
RumeliDE Dil ve Edebiyat Araștırmaları Dergisi Osmană̆a Mahallesi, Mürver Ciceği Sokak, No:14/8 Kadıköy - İSTANBUL / TÜRKIYE 34714 e-posta: editor@rumelide.com tel: +90 505 7958124, +90 2167730616

Address

RumeliDE Journal of Language and Literature Studies Osmanağa Mahallesi, Mürver Çiçeği Sokak, No:14/8

Kadıköy - ISTANBUL / TURKEY 34714

e-mail: editor@rumelide.com,

phone: +90 5057958124 , +90 2167730616
} 


\section{Tartışma, sonuç ve öneriler}

Yaratıcı yazma çok disiplinli yapısı ile yalnızca Türkçe ve sınıf eğitimi alanında değil diğer alanlarda da hak ettiği ilgiyi görmekte ve fen eğitimi hatta fizik eğitimi gibi alanlarda lisansüstü düzeyde ele alınmaktadır. Yazma fiili, bilinçli karakteristik özelliklere sahip olsa da kişilerin bilinçdışı yönlerinin dışa vurumu olabilir (Karabulut, 2020). Bu bağlamda ileri tarihlerde çok farklı disiplinlerde yaratıcı yazma konusunun ele alındığını görmemiz olasıdır. Araştırmada incelenen 51 tezden 7'si doktora düzeyindedir ve konu daha çok yüksek lisans düzeyinde ele alınmıştır. 51 tezden 21’i 2019 yllı ve sonrasında yürütülmüştür. Son iki yıldır Türkçe eğitimi alanında yaratıcı yazma konusuna karşı eğilimin arttı̆̆ı görülmektedir.

Kapsam belirlemenin doğası gereği tezlerdeki ifadelerden hareketle yaratıcı yazma ile ilgili netleşen ve birbiri yerine kullanılan kavramlar ele alındığında; tezler arası dilde "yaratıcı yazma becerisi” şeklinde bir kavramın oturduğu görülmektedir. Yaratıcı yazma etkinliği / çalışması / yaklaşımı / uygulaması / yöntemi / teknikleri ifadeleri ise birbiri yerine kullanılmakta ve netleşmemiş durumdadır. Yaratıcı yazmaya ilişkin tezlerin kapsam kurgusu ve hipotezleri ele alındığında, bazı hipotezlerin farklı çalışmalarda ortaklık gösterdiği görülmektedir. En çok tekrarlanan hipotezler; yaratıcı yazma etkinliklerinin yaratıcı yazmaya (5 tez) (Beydemir, 2010; Demirbaş, 2005; Gökçe, 2020; Karataş, 2019; Tonyalı, 2010), yazma becerisine (8 tez) (Akbaba, 2020; Ak, 2011; Beydemir, 2010; Erdoğan, 2012; Gökçe, 2020; Kasap, 2019; Korkmaz, 2015; Ylldırım, 2018), yazma tutumuna (12 tez) (Ak, 2011; Beydemir, 2010; Erdoğan, 2012; Gökçe 2020; İsbir-Abrekoşlu, 2019; Karadă̆; 2018; Kılıç, 2018; Korkmaz, 2015; Saluk, 2017; Türkel, 2011; Yüksel, 2016; Ylldırım, 2018), ders tutumuna (4 tez) (Başkök, 2012; Demirbaş, 2005; Karataş, 2020; Kapar Kuvanç, 2008) etkisi şeklindedir. En çok tekrar eden korelasyonel kapsam kurgusu ise bir x unsurunun yaratıcı yazmaya etkisi şeklindedir (18 tez).

Yaratıcı yazma tezlerinde, en çok ortaokul düzeyindeki öğrencilerle çalışılmıştır. Bu sonuçta 2012 ylına kadar 5 sinıfların ilkokul grubunda yer almasının etkisi bulunmaktadır. İlaveten bu sonuçla örtüşecek şekilde, Türkçe eğitimi alanında 2015 yllına kadar yapılmış tezleri inceleyen bir araştırma, tezlerin \%31,5’inin ortaokul, \%8.4'ünün ilkokul öğrencileri ile yürütüldüğünü göstermektedir (Özçakmak, 2017). Yaratıcı yazma tezlerini inceleyen mevcut araştırmada, ortaokul öğrencileri ile çalışılan 30 tez, ilkokul öğrencileri ile çalışılan 14 tez, lise öğrencileri ile çalışılan 3 tez bulunmaktadır. Yaratıcı yazma konusu lisansüstü düzeyde en az lise gruplarıyla ele alınmıştır. Diğerlerinden farklı olarak 2 tezde ortaokul düzeyindeki üstün yetenekli öğrencilerle çalışılmıştır. Öğrencilerle çalışılmayan 3 tez bulunmaktadır.

Yaratıcı yazma üzerine yazılmış 51 tezden $39^{\prime}$ unda ön ve son testli yarı deneysel model kullanılmıştır. Bu 39 tezden 13’ünde de "ön ve son testli yarı deneysel model + görüşme” şeklinde ikili desen kullanımı tercih edilmiştir. Tezlerdeki eğitimlerin uygulama süresi en kısa 4 hafta en uzun 18 hafta şeklindedir. En çok tercih edilen süre 12 haftadır. Tezlerde, test, ölçek, rubrik başlıklarında 57 farklı veri toplama aracı bulunsa da bu araçların 30'unun farklı amacı bulunmaktadır. Bu durumda 17 araç, amaçları bakımından birbirlerinin muadili haline gelmiştir. Örneğin tezlerde, yaratıcı yazma ürünlerini değerlendirmek üzere 12 farklı ölçme aracı kullanılmıştır. Bunun yanı sıra tezlerdeki 57 farklı veri toplama aracından 25’i yazarlar tarafından geliştirilmiş 32'si farklı çalışmalardan hazır olarak alınmıştır. Bazı veri toplama araçlarının çoklu kullanımı söz konusudur. Örneğin yaratıcı yazma ürünlerini değerlendirmek için geliştirilmiş bir rubrik 10 ayrı tezde, yine aynı amaçla geliştirilmiş farklı bir ölçek 10 ayrı tezde, yazmaya yönelik bir tutum ölçeği 7 ayrı tezde kullanılmıştır. Ölçme aracı geliştirmek derinlemesine araştırmaya ve zamana dayalıdır. Eğer ölçme aracına ihtiyaç varsa

\begin{tabular}{r|r} 
Adres & Address \\
RumeliDE Dil ve Edebiyat Arastrmaları Dergisi & RumeliDE
\end{tabular} Osmanağa Mahallesi, Mürver Çiçeği Sokak, No:14/8 Osmanağa Mahallesi, Mürver Çiçeği Sokak, No:14/8

Kadıköy - İSTANBUL / TÜRKIYE 34714 Kadıköy - ISTANBUL / TURKEY 34714 e-posta: editor@rumelide.com e-mail: editor@rumelide.com,

tel: +90 505 7958124, +90 2167730616 phone: +90 505 7958124, +90 2167730616 
An analytical analysis of theses about creative writing in Turkish education as a native language: A scoping review / S. Konuk (pp. 706-733)

lisansüstü düzeyde bir araştırmacıdan bir araç geliştirebilmesini veya uyarlayabilmesini beklemek, sıra dışı bir durum değildir. Burada anahtar kelimeler 'ihtiyaç varsa' ifadesidir. Bu araştırmanın sonuçlarına göre yaratıcı yazma tezlerinin kurgusal kapsamı benzeştikçe mevcut ölçme araçları yeterli hale gelmiş gibi görünmektedir. Bu çıkarımı, test, ölçek, rubrik başlıklarında ölçme araçlarının kullanıldığı 43 tezden 28'inde yazarların herhangi bir araç geliştirmeksizin hazır ölçme araçları kullanmaları desteklemektedir. Tezlerden bazılarında aynı ölçme araçlarının birbirine oldukça benzer şekilde de kullanıldığı görülmektedir (bk. Tablo 4 (sıra 13, 14)). Bu durum kronolojik olarak geç tarihli olanların öncekilerden daha az özgün olabileceği ihtimalini oluşturmaktadır. Özetle amacı, yöntemi, veri toplama araçları bakımından kronolojik olarak daha erken tarihli tezlerin sonrakilere oranla daha özgün olduğu görülmektedir. $\mathrm{Bu}$ konu yaratıcı yazma tezlerine yönelik sinırlılık olarak değerlendirilebilir. Sosyal ve beşerî bilimlerdeki dergilerin hakemleri özgünlüğü: yeni bir yaklaşım, teori, yöntem veya veri kullanarak yeni bir konu üzerinde çalışmak, yeterince çalışılmamış bir alanda araştırma yapmak veya yeni bulgular üretmek şeklinde tanımlamaktadır (Guetzkow ve ark., 2004). Özgünlük, her disiplinde lisansüstü aşamanın temel bileşenidir ve bazı ülkelerde, lisansüstü öğrencilerin, disiplinlerine yeni bilgilerle nasıl katkıda bulunduklarını ve tezlerinin özgünlüğünü sınav görevlilerine göstermeleri gerekmektedir (Alajami, 2020). Özgünlük, İngiltere'de, adayın lisansüstü derecesini geçip geçmemesi konusunda incelemecilerin kararları için esastır ve esas olmasına rağmen yeterli değildir, tezlerin özgünlüğü kadar bilgiye katkı yapması da beklenir (Clarke ve Lunt, 2014). Lisansüstü tezler, bir üniversitenin akademik ve entelektüel ürününün önemli bir kısmıdır ve öğrencilerle danışmanları, kendi alanlarına katkı sağlamak için uzun yıllar boyunca iş birliği, araştırma ve yazma işi ile meşgul olur (Middleton ve ark., 2015). Lisansüstü tezlerin özgünlüğü konusunda değerli kaynakların ve insanların zamanının boşa harcandığı konusunda giderek büyüyen bir anlayış bulunmakta ve araştırmacıların çoğu etik komitelerinde yer almak istememektedir (Alajami, 2020). Dünya çapındaki bu endişeler Türkiye için de geçerlidir. Türkiye'de 2007-2015 yılları arasında eğitim alanında yazılmış 600 yüksek lisans tezini inceleyen çalışmanın bulguları incelenen tezlerin \%34,5'inin intihal içerdiğini ve özgünlüğünün \%28,7 olduğunu göstermektedir (Toprak ve Yücel, 2020). Son yllarda tezler nihai olarak kabul edilmeden önce intihal programları tarafindan taranmaktadır. Bu taramalar büyük oranda intihal durumunu engellemektedir. Ancak bir eserde intihal olmaması o araştırmayı özgün yapmak için yeterli değildir. Lisansüstü eğitim bireyleri yetkin birer araştırmacı olmaya hazırlayan aşamadır. Öğrencilerin konu belirlemeden alanyazın taramaya kadar bir dizi sorun yaşaması kaçınılmazdır. Bu anlamda danışmanlardan öğrencilerin yaşadıkları zorlukları fark edip aşmaları için öğrencileri desteklemeleri beklenir. Ancak tez bağlamında düşünülürse alanyazın inceleme, yöntem bilgisi, temel istatistikler, etik konular, dijital beceriler gibi çok yönlü ve çok bileşenli desteğe ihtiyaç vardır ve bunu tek başına danışmandan ve öğrenciden beklemek doğru değildir. Pek çok konuda danışmanlara da destek ve bilgilendirme sağlanmalıdır. Örneğin tez önerisi verildiği aşamada tez danışmanı haricinde, üniversitenin veya Yüksek Öğretim Kurumunun kurmuş olduğu bir özgünlük komitesi öneriyi inceleyebilir. Burada amaç bitmiş bir tezin özgünlüğünü değerlendirmek değil henüz başlama aşamasında olan bir tez önerisinin değerlendirilmesi olmalıdır. Böylece zaman ve emek kaybının önüne geçilebilir. Bunun yanı sıra Middleton ve ark. (2015) bitmiş tezler kadar şu anda devam etmekte olan tezlerin de veri tabanlarında ulaşılabilir şekilde kataloglama sürecine girmesinin tezlerin orijinalliğine katkı sağlamada etkili olacağına dikkat çekmektedir. Bu araştırmada da aynı yılda aynı amaçları inceleyip benzer sonuçlara ulaşılan tezler olduğu görülmüştür. Bu durum tek başına tez danışmanı veya öğrencinin aşabileceği bir konu değildir. Yüksek Öğretim Kurumunun tez veri tabanına sürdürülmekte olan tezlerle ilgili bir bölüm eklenmesi ülke çapında yürütülen tezlerin özgünlüğünü artırabilir. Bunun yanı sıra bu araştırmanında yönteminde kullanılan kapsam belirleme incelemesi bir konudaki bilgi boşluklarını tespit etmek için oldukça elverişlidir. Danışmanlar ve

\footnotetext{
Adres Address

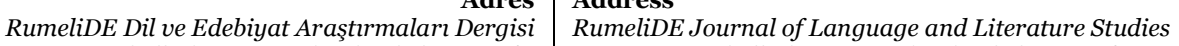
Osmanağa Mahallesi, Mürver Çiçeği Sokak, No:14/8 Osmanağa Mahallesi, Mürver Çiçeği Sokak, No:14/8 Kadıköy - İSTANBUL / TÜRKIYE 34714 Kadıköy - ISTANBUL / TURKEY 34714 e-posta: editor@rumelide.com e-mail: editor@rumelide.com, tel: +90 505 7958124, +90 2167730616 phone: +90 505 7958124, +90 2167730616
} 
öğrenciler tez çalışmasına başlamadan önce hedefledikleri konuyla ilgili bir kapsam belirleme incelemesi yürütebilir.

$\mathrm{Bu}$ bölümde araştırmada incelenen tezlerin temel bulgularına ilişkin sonuçlara ve tartışmaya yer verilmiştir. Çeşitli strateji veya unsurların yaratıcı yazmaya etkisini inceleyen 18 tezin tamamında öğrencilerin yaratıcı yazma becerileri kontrol grubu lehine olumlu yönde gelişmiştir. Yaratıcı yazmaya etkisi incelenen çeşitli strateji ve unsurlar şöyledir; metinler arası okuma yaklaşımı (Akdal, 2011), süreç temelli yazma modeli (Erdoğan, 2012; Sever, 2013), masallar (Urhan, 2012), masalların birleştirilmesi (Oğuz, 2017), tarihsel romanlar (Dolmaz, 2017), storybird uygulaması (Karadağ, 2018), ${ }_{5}$ E modeli (Dorlay, 2018), dijital hikâye (Demirtaş, 2019), işbirlikli dijital hikâye (Uslu, 2019), yansitıcı düşünme (Erdoğan, 2019), karikatür (Et, 2019), klasik Türk şiiri çeviri örnekleri (Kalaç, 2019), alternatif dinleme/izleme materyalleri (Uluyüz, 2019), Türk halk edebiyatı unsurları (Yılmaz, 2019), argümantasyon uygulamaları (Uç, 2019). Bahsi geçen tezler farklı bakış açıları ile yaratıcı yazmayı ele almışlardır. İncelenen iki tezde, Türkçe öğretim programlarındaki yazma kazanımlarının sınırlı bir bölümünün yaratıcı yazma becerisini desteklediği sonucuna ulaşılırken (Bulut, 2012; Uyğun, 2019), güncel tarihli farklı bir araştırma yazarlık ve yazma becerileri dersi öğretim programının da yaratıcılığa gereken önemi vermediği sonucunu rapor etmektedir (Başar ve Yavaşli, 2020). Ayrıca Türkçe ders kitaplarında yaratıcı yazma konusunu ele alan iki tezde, kitaplarda yaratıcı yazma etkinliklerinin yeterince yer almadığı çıarımına ulaşırken (Aydın, 2020; Uyğun, 2019) benzer tarihlerde yapılmış başka bir araştırmada beşinci sınıf Türkçe ders kitabında yer alan etkinliklerde öğrencilerin yaratıcılıklarını ve hayal gücünü geliştirecek birçok unsura rastlandığı, ders kitabındaki bütün temalarda hayal gücü eğitiminin bulunduğu raporlanmıştır (Ünveren, 2020). Ders kitapları konusu dinamik bir alan olduğundan konuyla ilgili farklı bakış açıları ile farklı araştırmalar yürütülmesi gerekmektedir. Bunun yanı sıra incelenen tezlerin temel bulgularına bakıldığında yaratıcı yazma etkinliklerinin yazma becerisini olumlu yönde etkilediği sonucu 2020 yllına kadar sekiz defa ortaya konulmuştur (Akbaba, 2020; Ak, 2011; Beydemir, 2010; Erdoğan, 2012; Gökçe, 2020; Kasap, 2019; Korkmaz, 2015; Yıldırım, 2018). Normal öğrencilerde, yaratıcı yazma etkinliklerinin yazma tutumunu geliştirdiği sonucu da sekiz defa ortaya konulmuştur (Ak, 2011; Beydemir, 2010; Erdoğan, 2012; Gökçe, 2020; Karadağ, 2018; Korkmaz, 2015; Yıldırım, 2018; Yüksel, 2016;). Yaratıcı dramanın yaratıcı yazma becerisini geliştirdiği dört defa ortaya konulmuştur (Erdoğan, 2018; Duman-Yegen, 2019; İsbir-Abrekoşlu, 2019; Türkel, 2011). Yaratıcı yazma etkinliklerinin Türkçe dersine tutumu olumlu yönde geliştirdiği sonucu üç defa ortaya konulmuştur. Belirli hipotezlerin farklı araştırmacılar tarafından denenip tekrar ortaya koyulması yaratıcı yazma alanındaki belirli konuları doygunluğa ulaştırması bakımından yararlıdır. Doygunluğa ulaşılan hipotezler yaratıcı yazma etkinliklerinin yaratıcı yazmaya, yazma becerisine, yazma tutumuna, Türkçe dersine tutumuna etkisi, yaratıcı dramanın yaratıcı yazmaya etkisi şeklindedir. Doygunluğa ulaşılan yöntem, ön ve son testli yarı deneysel model ve görüşme desenlerinin normal ortaokul ve ilkokul öğrencileriyle yürütülmesidir. Peki, doygunluk nedir? Nelson (2016) bir kavram olarak doygunluğun tanımını ve sürecini ortaya koymanın zorluklarına dikkat çeker ve bir dizi kavramsal derinlik kriteri oluşturmanın önemini vurgular. Bu kriterleri oluşturmak için araştırmacılar çalışmaktadır. Saunders ve ark. (2018) doygunluğu teorik doygunluk, tematik doygunluk ve veri doygunluğu şeklinde sinıflar. Veri doygunluğu yeni bilginin keşfedilmediği noktayı ifade eder (Faulkner ve Trotter, 2017) ve yeni bilgilerin araştırılanların anlaşılmasını değiştirmediği için toplanması gerekliliğ̆i ortadan kalkar (Nascimento ve ark., 2018). Araştırmacı, benzer örnekleri defalarca gördükçe, deneysel olarak bir kategorinin doygun olduğundan emin olabilir (Saunders ve ark., 2018). Doygunluk araştırmacılara bilgi birikimleri sunarak araştırılan konularla ilgili anlayışı yükseltir. Bunun yanı sıra başlangıç aşamasında araştırmacının amaçlarını netleştirmesine yardımcı olur ve gelecek araştırmalara yön verir 
(Saunders ve ark., 2018). Bu sayede araştırmacı konu ile ilgili ihtiyaçları belirleyebilir ve buna uygun bir araştırma yürütebilir. Eğitim araştırmalarının alanın ihtiyaçlarına göre yürütülmesi hayatidir, çünkü eğitim yaşayan somut bir alandır. Bu araştırmada incelenen tezlerde görüldüğü üzere tezlerin uygulaması gerçek ilkokul, ortaokul, lise ortamlarında yapılmıştır. Lisansüstü öğlencilerin uygulamaları sırasında kullandıkları ve olumlu sonuç veren her türlü ders materyalli, eylem planı, çalışama yaprağı, örnek metin, test, ölçek, rubrik, eğitim içeriği, pratik tavsiyeler, örnek teşkil edebilecek öğrenci ürünleri Millî Eğitim Bakanlığına, Eğitim Bilişim Ağı ders materyali veri deposuna eklenmek üzere sunulabilir. Böylelikle deneysel olarak test edilmiş materyaller, ihtiyaçları olduğu taktirde öğretmenlerin kullanımlarına hazır bir şekilde bulunacaktır. Bu sayede fakülte okul iş birliği kapsamında lisansüstü araştırmalardan birinci elden fayda sağlanabilir.

\section{Kaynakça}

Ak, E. (2011). Yaratıcı yazma tekniklerinin ilköğretim 5.sınıf öğrencilerinin Türkçe dersindeki yazılı anlatım becerileri üzerindeki etkisi [Yayınlanmamış yüksek lisans tezi]. Dokuz Eylül Üniversitesi.

Akbaba, R. S. (2020). Yaratıcı yazma çalışmalarının öyküleyici metin yazma becerisine ve ileri okuma farkındalığına etkisi [Yayınlanmamış doktora tezi]. Fırat Üniversitesi.

Akdal, D. (2011). Metinler arası okuma yaklaşımının ilköğretim beşinci sınıf öğrencilerinin yaratıcı yazma becerilerine etkisi [Yayınlanmamış yüksek lisans tezi]. Ahi Evran Üniversitesi.

Alajami, A. (2020). Beyond originality in scientific research: Considering relations among originality, novelty, and ecological thinking. Thinking Skills and Creativity, 38, 100723. https://doi.org/10.1016/j.tsc.2020.100723

Arksey, H., \& O’Malley, L. (2005). Scoping studies: Towards a methodological framework. International Journal of Social Research Methodology, 8, 19-32. https://doi.org/10.1080/1364557032000119616

Avcı, A. S. (2013). Yaratıcı yazma etkinliklerinin 8. sınıf öğrencilerinin yazma eğilimleri ve yazma kaygılarına etkisi [Yayınlanmamış yüksek lisans tezi]. Niğde Üniversitesi.

Aydın, B. (2020). Yaratıcı düşünmenin yaratıcı yazmaya etkisi [Yayınlanmamış yüksek lisans tezi]. Gazi Üniversitesi.

Bağcı Ayrancı, B. (2019). Türkiye'de yabancılara Türkçe öğretiminde kültür aktarımı alanında yapılan lisansüstü tezlerin analizi ve değerlendirilmesi. Söylem Filoloji Dergisi, 4(2), 446-454.

Barbot, B., Tan, M., Randi, J., Santa-Donato, G. ve Grigorenko, E. L. (2012). Essential skills for creative writing: Integrating multiple domain-specific perspectives. Thinking Skills and Creativity, 7(3), 209-223. https://doi.org/10.1016/j.tsc.2012.04.006

Başar, T. ve Yavaşlı, M. (2020). Yazarlık ve yazma becerileri dersi öğretim programına yönelik öğretmen görüssleri. Ana Dili Eğitimi Dergisi, 8(2), 270-291.

Başkök, B. (2012). İlköğretim yedinci sınıf öğrencilerinde uygulanan yaratıcı yazma çalışmalarının, öğrencilerin yaratıcılıklarına ve Türkçe dersine olan tutumlarına etkisinin incelenmesi [Yayınlanmamış yüksek lisans tezi]. Akdeniz Üniversitesi.

Bayer, M. (2019). Bazı yaratıcı yazma teknikleri kullanılarak lise öğrencilerinin fiziğe yönelik görüşlerinin belirlenmesi [Yayınlanmamış yüksek lisans tezi]. Balıkesir Üniversitesi.

Beydemir, A. (2010). İlköğretim 5. sınıf Türkçe dersinde yaratıcı yazma yaklaşımının yazmaya yönelik tutumlara, yaratıcı yazma ve yazma erişisine etkisi [Yayınlanmamış yüksek lisans tezi]. Pamukkale Üniversitesi.

Boyacı, S. ve Demirkol, S. (2018). Türkçe eğitimi alanında yapılan doktora tezlerinin incelenmesi. Ana Dili Eğitimi Dergisi, 6(2), 512-531.

\begin{tabular}{|c|c|}
\hline & \\
\hline alarn $D$ & d Literatur \\
\hline $\mathrm{Mal}$ & Mahallesi, Mürver Çiçeği Sokak, No:14/8 \\
\hline Kadıköy & STANBUL / TURKEY 34714 \\
\hline $\begin{array}{r}\text { e-posta: edito } \\
\text { tel: }+905057958124,+\end{array}$ & $\begin{array}{l}\text { editor@rumelide.com, } \\
\text { +90 505 7958124, +90 } 216773 \text { o } 616\end{array}$ \\
\hline
\end{tabular}


Bulut, K. (2012). 2006 Türkçe dersi (6, 7, 8. sınıflar) öğretim programında yer alan yazma kazanımlarının yaratıcı yazmaya uygunluğu [Yayınlanmamış yüksek lisans tezi]. Yüzüncü Yıl Üniversitesi.

Büyükikiz, K. (2014). Yabancılara Türkçe öğretimi alanında hazırlanan lisansüstü tezler üzerine bir inceleme. Mustafa Kemal Üniversitesi Sosyal Bilimler Enstitüsü Dergisi, 11(25), 203-213.

Castleberry, A., Ward, W. ve Stein, S. (2019). Lifelong learning inspires the creative art of academic writing. Currents in Pharmacy Teaching and Learning, 11(8), 757-759. https://doi.org/10.1016/j.cptl.2019.04.002

Clarke, G. ve Lunt, I. (2014). The concept of 'originality' in the Ph.D.: How is it interpreted by examiners? Assessment \& Evaluation in Higher Education, 39(7), 803-820. https://doi.org/10.1080/02602938.2013.870970

Dalkılıç Fer, T. (2017). İlköğretim öğrencilerinin yaratıcı yazı çalışmalarının süreç içerisindeki gelişimlerinin incelenmesi ve değerlendirilmesi [Yayınlanmamış yüksek lisans tezi]. Bahçeşehir Üniversitesi.

Demir, T. (2011). İlköğretim öğrencilerinin yaratıcı yazma becerileri ile yazma özyeterlik algısı ve başarı amaç yönelimi türleri ilişkisinin değerlendirilmesi [Yayınlanmamış doktora tezi]. Gazi Üniversitesi.

Demirbaş, A. (2005). Biyoloji öğretiminde yaratıcı yazma uygulamaları [Yayınlanmamış yüksek lisans tezi]. Balıkesir Üniversitesi.

Demirbaş, İ. (2019). Dijital öykülerin ilkokul öğrencilerinin dinlediğini anlama ve yaratıcı yazma becerilerine etkisi [Yayınlanmamış yüksek lisans tezi]. Kırşehir Ahi Evran Üniversitesi.

Deveney, C. (2020): Psychology and creative writing: the role of experiential learning in the journey from fact to fiction, and the implications for therapy, Journal of Poetry Therapy. https://doi.org/10.1080/08893675.2020.1846864

Direkci, B., Akbulut, S., ve Şimşek, B. (2020). Türkçe eğitimi alanında yapılan değerler eğitimi tezlerinin incelenmesi. Zeitschrift für die Welt der Türken/Journal of World of Turks, 12(2), 117140 .

Doğan, Y. ve Özçakmak, H. (2014). Dinleme becerisinin eğitimi üzerine yapılan lisansüstü tezlerin değerlendirilmesi. Ana Dili Ĕ̆itimi Dergisi, 2(2), 90-99.

Dolmaz, M. (2017). Sosyal bilgiler öğretiminde tarihsel roman kullanımının yaratıcı yazma becerilerine etkisi [Yayınlanmamış doktora tezi]. Erzincan Üniversitesi.

Dorlay, O. (2018). $5 \mathrm{E}$ öğrenme modeline uygun yaratıcı yazma etkinliklerinin ortaokul öğrencilerinin yazma becerisi üzerine etkisi [Yayınlanmamış yüksek lisans tezi]. Kırıkkale Üniversitesi.

Duman Yeğen, G. (2019). İlkokul 3. sınıf öğrencilerinin yaratıcı yazma becerilerinin yaratıcı drama yöntemiyle geliştirilmesine yönelik bir eylem araştırması [Yayınlanmamış yüksek lisans tezi]. Burdur Mehmet Akif Ersoy Üniversitesi.

Duran, S. (2010). Yaratıcı yazma yaklaşımının yazılı anlatım becerisinin gelişimine etkisi. [Yayınlanmamış yüksek lisans tezi]. Trakya Üniversitesi.

Duru, A. (2014). Altıncı sınıf öğrencilerinin yaratıcı yazma becerilerini geliştirmeye yönelik stratejilerin etkililiğinin değerlendirilmesi [Yayınlanmamış yüksek lisans tezi]. Niğde Üniversitesi.

Erdoğan, Ö. (2012). Süreç temelli yaratıcı yazma uygulamalarının yazılı anlatım becerisine ve yazmaya ilişkin tutuma etkisi [Yayınlanmamış doktora tezi]. Hacettepe Üniversitesi.

Erdoğan, R. (2019). İlkokul 4. sınıf Türkçe dersinde yansıtıcı düşünme destekli yaratıcı yazma çalışmalarının öğrencilerin yaratıcı yazma becerilerine etkisinin incelenmesi [Yayınlanmamış yüksek lisans tezi]. Recep Tayyip Erdoğan Üniversitesi.

Et, E. (2019). Karikatürle yazma çalışmalarının ortaokul öğrencilerinin yaratıcı yazma becerisine etkisi [Yayınlanmamış yüksek lisans tezi]. Kırşehir Ahi Evran Üniversitesi.

\begin{tabular}{r|l} 
Adres & Address \\
RumeliDE Dil ve Edebiyat Araştırmaları Dergisi & RumeliDE Journal of Language and Literature Studies \\
Osmanağa Mahallesi, Mürver Çiçeği Sokak, No:14/8 & Osmanağa Mahallesi, Mürver Çiçeği Sokak, No:14/8 \\
Kadıköy - İSTANBUL / TÜRKIYE 34714 & Kadıköy - ISTANBUL / TURKEY 34714 \\
e-posta: editor@rumelide.com & $\begin{array}{l}\text { e-mail: editor@rumelide.com, } \\
\text { phone: +90 505 7958124, +90 } 216773 \text { o } 616\end{array}$
\end{tabular}


An analytical analysis of theses about creative writing in Turkish education as a native language: A scoping review / S. Konuk (pp. 706-733)

Fair, C. D., Connor, L., Albright, J., Wise, E. ve Jones, K. (2012). "I'm positive, I have something to say": Assessing the impact of a creative writing group for adolescents living with HIV. The Arts in Psychotherapy, 39(5), 383-389. https://doi.org/10.1016/j.aip.2012.06.010

Faulkner, S. L. ve Trotter, S. P. (2017). Data Saturation. Wiley Online Library. https://doi.org/10.1002/9781118901731.iecrmoo6o

Gökçe, A. (2020). İlkokul dördüncü sınıf Türkçe dersinde yaratıcı yazma uygulamalarının öğrencilerin Türkçe dersi tutumu, yazma tutumu ve yaratıcı yazma becerileri üzerine etkisi [Yayınlanmamış yüksek lisans tezi]. Yozgat Bozok Üniversitesi.

Guetzkow, J., Lamont, M. \& Mallard, G. (2004). What is Originality in the Humanities and the Social Sciences? American Sociological Review, 69(2), 190-212. https://doi.org/10.1177/000312240406900203

Hatem, D. ve Ferrara, E. (2001). Becoming a doctor: fostering humane caregivers through creative writing. Patient Education and Counseling, 45(1),13-22. https://doi.org/10.1016/So7383991(01)00135-5

İsbir Abrekoğlu, B. (2019). Yaratıcı dramanın yaratıcı yazma becerisine ve yazmaya yönelik tutuma etkisi [Yayınlanmamış doktora tezi]. Düzce Üniversitesi.

Kalaç, A. (2019). Klasik Türk edebiyatı çeviri örneklerinin yaratıcı yazma becerilerine katkısı [Yayınlanmamış yüksek lisans tezi]. Muğla Sıtkı Koçman Üniversitesi.

Kan, M. O. (2017). Türkiye'de akademik yazma alanında yapılan lisansüstü tezler. İnsan ve Toplum Bilimleri Araştırmaları Dergisi, 6(2), 1037-1048.

Kapar Kuvanç (2008). Yaratıcı yazma tekniklerinin öğrencilerin Türkçe dersine ilişkin tutumlarına ve Türkçe dersindeki başarılarına etkisi [Yayınlanmamış yüksek lisans tezi]. Dokuz Eylül Üniversitesi.

Karabulut, M. (2020). Psikanalitik bakış açısıyla sanat, sanatçı ve yazma dürtüsü. Türk Kültürü ve Medeniyeti Araştırmaları Dergisi, 1 (2), 12-19.

Karadağ, K. (2018). Öğretim teknolojilerinden Storybırd uygulamasının 5. sınıf öğrencilerinin yaratıcı yazma becerilerine ve yazmaya yönelik tutumlarına etkisi [Yayınlanmamış yüksek lisans tezi]. Marmara Üniversitesi.

Karagöz, B. ve Şeref, İ. (2020). Yazma becerisiyle ilgili makaleler üzerine bir inceleme: Web of Science veri tabanında eğilimler. Ana Dili Eğitimi Dergisi, 8(1), 67-86.

Karataş, G. (2019). Sorumluluk değerinin yaratıcı yazma teknikleri ile oluşturulan etkinliklerle kazandırılmasının öğrencilerin sorumluluk düzeyine etkisi [Yayınlanmamış yüksek lisans tezi]. Atatürk Üniversitesi.

Karataş, Y. (2020). İlkokul dördüncü sınıf öğrencilerinin yaratıcı hikâye yazma becerilerinin geliştirilmesi [Yayınlanmamış yüksek lisans tezi]. Uşak Üniversitesi.

Kasap, D. (2019). Yaratıcı okuma-yaratıcı yazma çalışmalarının yaratıcı okuma, okuduğunu anlama, yazma ve yaratıcı yazma erişisine etkisi [Yayınlanmamış doktora tezi]. Pamukkale Üniversitesi.

Keşaplı, G. (2019). Yaratıcı dramayla planlanmış Türkçe eğitimi ve öğretimi alanındaki lisansüstü çalışmalara genel bir bakış. Avrasya Dil Eğitimi ve Araştırmaları Dergisi, 3(1), 77-94.

Kılıç, Ü. (2018). 9. sınıf öğrencilerine uygulanan drama yöntemine dayalı yaratıcı yazma çalışmalarının yazma tutumuna etkisinin incelenmesi [Yayınlanmamış yüksek lisans tezi]. Marmara Üniversitesi.

Kırbaş, B. (2010). Yeni Türkçe ders programına göre ilköğretim yedinci sınıf öğrencilerinin yaratıcı yazma çalışmalarının yazım noktalama ve planlama açısından değerlendirilmesi [Yayınlanmamış yüksek lisans tezi]. Atatürk Üniversitesi.

Korkmaz, G. (2015). Yaratıcı yazma yönteminin 6. sınıf öğrencilerinin yazma öz yeterlik algılarına, yazmaya ilişkin tutumlarına ve yazma becerisi akademik başarılarına etkisi [Yayınlanmamış yüksek lisans tezi]. Gaziantep Üniversitesi.

\begin{tabular}{|c|c|}
\hline Adres & Address \\
\hline $\operatorname{arl} D$ & RumeliDE Journal of Language and Literature Studies \\
\hline 8 & Osmanağa Mahallesi, Mürver Çiçeği Sokak, No:14/8 \\
\hline $\begin{array}{r}\text { Kadıköy - ISTANBUL / TÜRKIYE } 34714 \\
\text { e-posta: editor@rumelide.com } \\
\text { tel: +90 } 5057958124,+902167730616\end{array}$ & $\begin{array}{l}\text { Kadıköy - ISTANBUL / TURKEY } 34714 \\
\text { e-mail: editor@rumelide.com, } \\
\text { phone: +90 } 5057958124,+90216773 \text { o } 616\end{array}$ \\
\hline
\end{tabular}


Levac, D., Colquhoun, H., \& O’Brien, K. K. (2010). Scoping studies: Advancing the methodology. Implementation Science, 5, 1-9. https://doi.org/10.1186/1748-5908-5-69.

Maden, A. (2020). Akıcı okuma ile ilgili lisansüstü tezlerin araştırma eğilimleri: Bir betimsel analiz çalışması. Ana Dili Eğitimi Dergisi, 8(2), 543-558.

Maltepe, S. (2006). Yaratıcı yazma yaklaşımı açısından Türkçe derslerindeki yazma süreçlerinin ve ürünlerinin değerlendirilmesi [Yayınlanmamış doktora tezi]. Ankara Üniversitesi.

McVey, D. (2008). Why all writing is creative writing. Innovations in Education and Teaching International, 45(3), 289-294. https://doi.org/10.1080/14703290802176204

Middleton, C. C., Dean, J. W. \& Gilbertson, M. A. (2015). A Process for the Original Cataloging of Theses and Dissertations. Cataloging \& Classification Quarterly, 53(2), 234-246. https://doi.org/10.1080/01639374.2014.971997

Munn, Z., Peters, M.D.J., Stern, C., Tufanaru, C., McArthur, A., \& Aromataris, E. (2018). Systematic review or scoping review? Guidance for authors when choosing between a systematic or scoping review approach. BMC Med Res Methodol, 18, 143. https://doi.org/10.1186/s12874-018-0611-x

Nascimento, L. C. N., Souza, T. V., Oliveira, I. C. S., Moraes, J. R. M. M., Aguiar, R. C. B. ve Silva, L. F. (2018). Theoretical saturation in qualitative research: an experience report in an interview with schoolchildren. Revista Brasileira de Enfermagem, 71(1), On-line version ISSN 1984-0446. http://dx.doi.org/10.1590/0034-7167-2016-0616

Nelson, J. (2016). Using conceptual depth criteria: addressing the challenge of reaching saturation in qualitative research. Qualitative Research, 17(5), 554-570. https://doi.org/10.1177/1468794116679873

Oğuz, S. G. (2017). Masalları birleştirme yoluyla ortaokul öğrencilerinin yaratıcı yazma becerilerinin incelenmesi [Yayınlanmamış yüksek lisans tezi]. İnönü Üniversitesi.

Özbaşı, S., \& Kalenderoğlu, İ. (2020). Türkçe eğitimi ve çocuk edebiyatında "toplumsal cinsiyet" üzerine yapılmış lisansüstü tezlerin değerlendirilmesi. IBAD Sosyal Bilimler Dergisi, 84-94.

Özçakmak, H. (2017). Türkçe eğitimi lisansüstü araştırmalarında yeni yönelimler (2011-2015). Uluslararası Türkçe Edebiyat Kültür Eğitim Dergisi, 6(3), 1607-1618.

Özdemir, Ö. (2010). Üstün yetenekli öğrencilerde yaratıcı yazma çalışmalarının düzeyleri ilköğretim 6, 7, 8. sınıf örneği [Yayınlanmamış yüksek lisans tezi]. Marmara Üniversitesi.

Peker, Ş. (2015). Yazılı anlatım becerilerinin geliştirilmesinde yaratıcı drama tekniklerinden özel mülkiyet tekniğinin yaratıcı yazma yaklaşımı ile karşılaştırılması [Yayınlanmamış yüksek lisans tezi]. Ankara Üniversitesi.

Pham, M. T., Rajić, A., Greig, J. D., Sargeant, J. M., Papadopoulos, A., \& Mcewen, S. A. (2014). A scoping review of scoping reviews: Advancing the approach and enhancing the consistency. Research Synthesis Methods, 5, 371-385. https://doi.org/10.1002/jrsm.1123.

Punzi, E. (2020): Creative writing at a Swedish psychiatric inpatient clinic. Perspectives from the authors who guided the patients. An interview study, Journal of Poetry Therapy. https://doi.org/10.1080/08893675.2020.1846867

Razgatlığlu, M. (2020). Etkinlik temelli şiir çalışmalarının akııı okuma, yaratıcı yazma ve tutumlara etkisi [Yayınlanmamış doktora tezi]. Gazi Üniversitesi.

Rebecca, M. (2016). The education of the creative writing teacher: A study of conceptions of creative writing pedagogy in higher education [Unpublished doctoral dissertation]. University of Michigan.

Saluk, N. (2017). Üstün yeteneklilerde yaratıcı yazma becerilerinin geliştirilmesi üzerine bir araştırma [Yayınlanmamış yüksek lisans tezi]. Kırıkkale Üniversitesi.

Saunders, B., Sim, J., Kingstone, T., Baker, S., Waterfield, J., Bartlam, B., Burroughs, H. \& Jinks, C. (2018). Saturation in qualitative research: exploring its conceptualization and operationalization. Qual Quant 52, 1893-1907. https://doi.org/10.1007/s11135-017-0574-8

\footnotetext{
\begin{tabular}{r|l} 
Adres & Address \\
RumeliDE Dil ve Edebiyat Araşttrmaları Dergisi & RumeliDE Journal of Language and Literature Studies
\end{tabular} Osmanağa Mahallesi, Mürver Çiçeği Sokak, No:14/8 Osmanağa Mahallesi, Mürver Çiçeği Sokak, No:14/8 Kadıköy - İSTANBUL / TÜRKIYE 34714 Kadıköy - ISTANBUL / TURKEY 34714 e-posta: editor@rumelide.com e-mail: editor@rumelide.com tel: +90 505 7958124, +90 2167730616 phone: +90 505 7958124, +90 2167730616
} 
An analytical analysis of theses about creative writing in Turkish education as a native language: A scoping review / S. Konuk (pp. 706-733)

Sever, E. (2013). Süreç temelli yazma modellerinin ilkokul dördüncü sınıf öğrencilerinin yazılı anlatım ve yaratıcı yazma becerilerine etkisi [Yayınlanmamış yüksek lisans tezi]. Bülent Ecevit Üniversitesi.

Skains, L. R. (2017). The Adaptive Process of Multimodal Composition: How Developing Tacit Knowledge of Digital Tools Affects Creative Writing. Computers and Composition, 43, 106-117. https://doi.org/10.1016/j.compcom.2016.11.009

Şeref, İ. (2019). Türkçe öğretiminde şiir üzerine yapılan lisansüstü tezlerin değerlendirilmesi. Iğdır Üniversitesi Sosyal Bilimler Dergisi, 20, 335-350.

Taç, İ. (2020). Araştırmacı yazma yaklaşımının ilkokul 3. sınıf öğrencilerinin yaratıcı ve akıcı hikâye yazma becerisine etkisi [Yayınlanmamış yüksek lisans tezi]. Muğla Sttkı Koçman Üniversitesi.

Tan, M. ve Grigorenko, E. L. (2013). All in the family: Is creative writing familial and heritable? Learning and Individual Differences, 28, 177-180. https://doi.org/10.1016/j.lindif.2012.09.002

Thomson, L. (2013). Learning to Teach Creative Writing. Changing English, 20(1), 45-52. https://doi.org/10.1080/1358684X.2012.757060

Tonyalı, E. (2010). Yaratıcı yazma uygulamalarının ilköğretim altıncı sınıf öğrencilerinin yazma becerilerine etkisi [Yayınlanmamış yüksek lisans tezi]. Abant İzzet Baysal Üniversitesi.

Toprak, Z. ve Yücel, V. (2020). A peculiar practice of academic writing: Epidemic writing in the $\begin{array}{lllll}\text { Turkish graduate } & \text { education. Cogent } & \text { Education, } & \text { 7(1), } & 1774098 .\end{array}$ https://doi.org/10.1080/2331186X.2020.1774098

Turnbull, B. (2019). Translanguaging in the planning of academic and creative writing: A case of adult Japanese EFL learners. Bilingual Research Journal, 42(2), 232-251. https://doi.org/10.1080/15235882.2019.1589603

Türkel, A. (2011). Yaratıcı dramanın yaratıcı yazma başarısına ve yazmaya karşı tutuma etkisi (ilköğretim 8. sınıf) [Yayınlanmamış doktora tezi]. Dokuz Eylül Üniversitesi.

Uç, F. B. (2019). Yazma destekli argümantasyon uygulamalarının 7.sınıf öğrencilerinin yazma öz yeterliklerine, yaratıcı yazmalarına ve kavram öğrenmelerine etkisinin incelenmesi [Yayınlanmamış yüksek lisans tezi]. Marmara Üniversitesi.

Uluyüz, Ş. (2019). Alternatif dinleme/izleme materyallerinin ortaokul öğrencilerinin yaratıcı yazma becerilerine etkisi [Yayınlanmamış yüksek lisans tezi]. Kırıkkale Üniversitesi.

Urhan, O. (2016). Ortaokul 8. sınıf Türkçe derslerinde masalların yaratıcı yazma becerisine etkisi [Yayınlanmamış yüksek lisans tezi]. Muğla Sttkı Koçman Üniversitesi.

Uslu, A. (2019). İşbirlikli dijital hikâye anlatımının ilkokul 4. sınıf öğrencilerinin yaratıcı yazma ve sosyal duygusal öğrenme becerilerine etkisi [Yayınlanmamış yüksek lisans tezi]. Manisa Celal Bayar Üniversitesi.

Uyğun, A. (2019). 2018 Türkçe dersi öğretim programındaki yazma kazanımlarının ve ders kitaplarındaki etkinliklerin yaratıcı yazma becerisine uygunluğunun incelenmesi [Yayınlanmamış yüksek lisans tezi]. Muğla Sıtkı Koçman Üniversitesi.

Ünveren, D. (2020). Türkçe Öğretiminde Hayal Gücü ve Yaratıcılık Eğitimi, Uluslararası Toplum Araştırmaları Dergisi, 15(21), 378-404.

Vass, E. (2007). Exploring processes of collaborative creativity-The role of emotions in children's joint creative writing. Thinking Skills and Creativity, 2(2), 107-117. https://doi.org/10.1016/j.tsc.2007.06.001

Vass, E., Littleton, K., Miell, D. ve Jones, A. (2008). The discourse of collaborative creative writing: Peer collaboration as a context for mutual inspiration. Thinking Skills and Creativity, 3(3), 192202. https://doi.org/10.1016/j.tsc.2008.09.001

Yıldırım, G. (2018). Yaratıcı yazma etkinliklerinin Türkçe öğretmeni adaylarının yazma becerisine etkisi [Yayınlanmamış yüksek lisans tezi]. Çanakkale Onsekiz Mart Üniversitesi.

\begin{tabular}{|c|c|}
\hline Adres & Address \\
\hline $\operatorname{arl} D$ & RumeliDE Journal of Language and Literature Studies \\
\hline 8 & Osmanağa Mahallesi, Mürver Çiçeği Sokak, No:14/8 \\
\hline $\begin{array}{r}\text { Kadıköy - ISTANBUL / TÜRKIYE } 34714 \\
\text { e-posta: editor@rumelide.com } \\
\text { tel: +90 } 5057958124,+902167730616\end{array}$ & $\begin{array}{l}\text { Kadıköy - ISTANBUL / TURKEY } 34714 \\
\text { e-mail: editor@rumelide.com, } \\
\text { phone: +90 } 5057958124,+90216773 \text { o } 616\end{array}$ \\
\hline
\end{tabular}


Yılmaz, M. (2019). Türk halk edebiyatı unsurlarının Türkçe öğretiminde kullanımı ve yaratıcı yazmaya etkisi [Yayınlanmamış yüksek lisans tezi]. Muğla Sıtkı Koçman Üniversitesi.

Yoo, J. (2017). Writing out on a limb: integrating the creative and academic writing identity. New Writing, 14(3), 444-454. https://doi.org/10.1080/14790726.2017.1317274

Yüksel, T. (2016). Ortaokul 5.sınıf Türkçe derslerinde uygulanan yaratıcı yazma etkinliklerinin öğrencilerinin yazmaya yönelik tutumlarına ve sözel yaratıcılıklarına etkisinin incelenmesi [Yayınlanmamış yüksek lisans tezi]. Akdeniz Üniversitesi. 